\title{
Potential of Energy Savings in the Public Housing Stock of Comunitat Valenciana Region by Applying the MedZEB Cost-Optimal Methodology
}

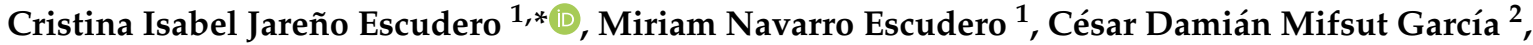 \\ María Flores Fillol ${ }^{2}$ and José Manuel Salmerón Lissen ${ }^{3}$ (D) \\ 1 Instituto Valenciano de la Edificación, Tres Forques, 98, 46018 Valencia, Spain; mnavarro@five.es \\ 2 Entitat Valenciana d'Habitatge i Sòl, C/Vinatea, 14, 46001 Valencia, Spain; mifsut_ces@gva.es (C.D.M.G.); \\ flores_marfil@gva.es (M.F.F.) \\ 3 Engineering School, University of Seville, Avda Camino de los Descubrimientos S/N, 41092 Seville, Spain; \\ jms@us.es \\ * Correspondence: cjareno@five.es
}

check for

updates

Citation: Jareño Escudero, C.I.;

Navarro Escudero, M.; Mifsut García,

C.D.; Flores Fillol, M.; Salmerón

Lissen, J.M. Potential of Energy

Savings in the Public Housing Stock of Comunitat Valenciana Region by

Applying the MedZEB Cost-Optimal Methodology. Appl. Sci. 2022, 12, 138. https://doi.org/10.3390/app12010138

Academic Editor: Constantinos

A. Balaras

Received: 20 October 2021

Accepted: 21 December 2021

Published: 23 December 2021

Publisher's Note: MDPI stays neutral with regard to jurisdictional claims in published maps and institutional affiliations.

Copyright: (C) 2021 by the authors. Licensee MDPI, Basel, Switzerland. This article is an open access article distributed under the terms and conditions of the Creative Commons Attribution (CC BY) license (https:// creativecommons.org/licenses/by/ $4.0 /)$.
Featured Application: Calculation of total primary energy savings per year (MW/h) of a building stock in Mediterranean countries following the cost-optimal methodology.

\begin{abstract}
Improving energy efficiency in buildings has a key role to play in achieving the ambitious goal of EU-wide climate neutrality by 2050, set out in the European Green Deal. This paper describes a cost-optimal analysis of residential buildings of Valencian Community, Spain. Thus, an assessment of the contribution of total primary energy savings per year $(\mathrm{MW} / \mathrm{h})$ of the social dwellings managed by EVha, Entitat Valenciana d'Habitatge i Sòl (eng. Valencian entity for dwelling and ground) towards the national contribution is presented in this paper. To assess it, the MedZEB cost-optimal methodology has been applied to optimise the performance of the building's envelope. This means that Optimal Renovation Strategies through Life-Cycle Analysis have been applied to obtain the Packages of Optimal Solutions of the different reference buildings in a reference climate. First, the renovation scenario with $100 \%$ of the building stock being renovated has been calculated. Then, the renovation scenario of $1 \%$, being the current European rate of renovation and, finally the renovation scenario of $2 \%$, given that the objective of the Renovation Wave is to at least double the annual energy renovation rate of residential and non-residential buildings by 2030 and to foster deep energy renovations.
\end{abstract}

Keywords: cost-optimal methodology; MedZEB; housing stock; energy savings; Mediterranean; passive measures; Package of Optimal Solutions; LCC; renovation; pilot buildings

\section{Introduction}

Collectively, buildings in the EU are responsible for $40 \%$ of our energy consumption and $36 \%$ of greenhouse gas emissions, which mainly stem from construction, usage, renovation, and demolition [1].

Improving energy efficiency in buildings therefore has a key role to play in achieving the ambitious goal of carbon-neutrality by 2050, set out in the European Green Deal. Renovating existing buildings could reduce the EU's total energy consumption by $5-6 \%$ and lower carbon dioxide emissions by about $5 \%$. Yet, on average, less than $1 \%$ of the national building stock is renovated each year. (Member State rates vary from $0.4 \%$ to $1.2 \%$ ). In order to meet our climate and energy objectives, the current rates of renovations should at least double [1]. In fact, the strategy of the "Renovation Wave for Europe-Greening our buildings, creating jobs, improving lives" aims to double annual energy renovation rates by 2030 and to foster deep energy renovations of both residential and non-residential 
buildings [2]. The increased rate and depth of renovation will have to be maintained also post 2030, in order to reach EU-wide climate neutrality by 2050 [3].

Different studies have been carried out to assess the energy efficiency of different type of buildings by using different methodologies and focusing on different renovation strategies.

Guardigli et al. performed the cost optimal analysis of energy retrofit alternatives in the case of a large housing stock owned by a semi-public real estate company, with the goal of meeting nearly zero energy building standards according to Italian regulations. The proposed method focuses on major energy renovation alternatives, given the assumption that interventions take place only when social and political conditions are favourable [4]. The thermal systems are considered in the renovation of three buildings. The result of this study was a design support system (DSS) providing the annual savings in terms of $\left(€ / \mathrm{m}^{2}\right)$. In the present study, the methodology used also considers the cost-optimal analysis [5]; however, the total primary energy savings per year $(\mathrm{MW} / \mathrm{h})$ of the social dwelling stock for three scenarios according to three renovation rates were assessed, and the thermal systems were not included as possible renovation solutions [6,7], as explained in Section 4.

Energy simulations supported by a cost-optimal methodology have been used to design the renovation of historic buildings [8], which is a methodology that has been proved to be needed when involving in-depth renovation of buildings $[9,10]$. This study reinforces the goodness of the cost-optimal methodology; however, the present paper is not focused on historic buildings. It is focused just on residential buildings, given that some of the renovation measures, such as external insulation on the façade, could be applied.

Brambilla et al. [11] analysed the renovation of a pilot office building in a warm climate following an LCA methodology. The main difference with the present study is that the building was for office use rather than residential.

Ortiz et al. have evaluated the potential of energetic savings of the dwellings in Catalonia and its economic impact, according to different scenarios of efficiency that have been defined according to their current regulations at state and autonomic level [12]. Passive and active measures have been considered for the refurbishment of residential buildings following the cost-optimal methodology of the European Directives. However, this paper describes a cost-optimal analysis of a residential building of Catalonia and proposes a cost-effective evaluation divided in two steps: first a passive evaluation, where the envelope performance is improved using thermal comfort and initial investment costs as a criteria of decision; and a second step, active evaluation, where the passive and actives measures are combined and evaluated using the global cost and the non-primary energy consumption to find the cost-optimal scenario. In comparison, this present paper proposes passive measures providing the results for the whole building stock, not only for a building.

Pernetti et al. have studied the potential renovation rate [13] providing also an estimation of the potential savings in energy consumptions and $\mathrm{CO}_{2}$ emissions occurring in case of deep renovation, but using a repository of Deep Renovation Packages Based on Industrialized Solutions [14]. In this study, the repository of deep renovation packages is based on solutions with specific technologies, among all industrialised elements, whose implementation requires significant investments. The present paper addresses technologies adapted to the European Mediterranean area where industrialised solutions are not usual yet.

In the Mediterranean area, Salvati et al. have focused on studying the Urban Heat Island (UHI) effect, as climate change and UHI scenarios foresee a fast growth of energy consumption for next years, due to the widespread of air conditioning systems and the increase of cooling demand. This study investigates the intensity of UHI in Barcelona (Spain), a Mediterranean coastal city, and its impact on the cooling demand of residential buildings [15].

Dalla Mora et al. [16] applied the cost-optimal methodology in two school buildings located in the North-East of Italy by defining different measures of energy retrofitting in both the building envelope and the heating system. The results showed that the methodology is suitable to assess cost-optimality and energy efficiency in the renovation of school 
buildings. In comparison, the present paper applies the cost-optimal methodology in a residential building stock.

Liébana-Durán et al. [17] also focused on school buildings in the city of Valencia when applying the cost-optimal methodology to carry out studies for the energy renovation of their thermal envelope. Again, the difference with the present paper is the type of buildings per use, i.e., the residential buildings.

Nevertheless, none of these studies has evaluated the potential of energy savings of a building stock (at regional level in this case) by using the MedZEB approach [18], i.e., looking for beyond deep renovation by using optimal renovation strategies through life-cycle analysis adapted to Mediterranean Climate.

After analysing the current research context, we can determine the main novelties proposed in this paper:

- The renovation measures used to evaluate the potential energy savings are adapted to the Mediterranean Area [18].

- $\quad$ The renovation measures have been optimized following the LCC methodology proposed by the European commission in the recast of the directive of energy efficiency of buildings [19].

- $\quad$ The impact of implementing the renovation measures in a big scale context (the whole EVha's social housing stock management in Comunitat Valenciana which represent 4319 blocks containing 35,571 dwellings) has been assessed.

\section{Materials and Methods}

First, the MedZEB approach developed within the framework of the HAPPEN project should be explained. The MedZEB (Mediterranean Zero Energy Building) approach aims at stimulating the market uptake of energy deep and beyond retrofitting of existing buildings of the Mediterranean [18]. Its holistic nature implies the evaluation and integration of a range of relevant factors and the effective support to the retrofitting supply chain, also with the help of an ICT open platform [20]. The main features of the MedZEB approach are holistic, transparent, and adaptive, giving the possibility for a step-by-step renovation approach.

This study calculates the total primary energy savings per year $(\mathrm{MW} / \mathrm{h})$ that could be obtained in Comunitat Valenciana region if the public residential building stock of Entitat Valenciana d'Habitatge i sol (EVha) was renovated applying Optimal Renovation Strategies through Life-Cycle Analysis. This methodology optimizes the performance of the building's envelope and its domestic hot water (DHW) and ventilation systems considering not only energy savings but also the investment and the operating costs [5].

This methodology has been applied in four pilot buildings in Cyprus, Croatia, France, and Spain (Table 1) of four different Mediterranean countries representing the more frequent climates (W1S2, W2S2, W2S3, and W3S2) in the Mediterranean area as developed in the framework of the H2020 HAPPEN project.

As a result, a set of 16 pre-evaluated Packages of Optimal Solutions (POS) with renovation measures were obtained, one per combination of building and climate. This set of 16 pre-evaluated POS have been called the preliminary POS (Table 2).

It is important to clarify that each POS is defined as the whole set of solutions near to the optimal point with the minimum life cycle cost. To this end, the solutions with a LCC up to $5 \%$ higher than the minimum were determined. Then, the solutions with an increase of $5 \%$ of Primary Energy Consumption with regards to the optimal point were determined. Among these solutions, 12 were selected as the representative of the POS [5].

Therefore, although all the solutions in the POS minimize the life cycle cost, one is the absolute minimum, and the rest are close to it. Thus, it was possible not to limit the renovation of the building to a unique set of measures, and to increase the flexibility and the degree of freedom on behalf of the architect or engineer involved in the refurbishment process. 
Table 1. Reference buildings characteristics.

\begin{tabular}{|c|c|c|c|c|}
\hline & SFH17 & SFH13 & MFH4 & MFH1 \\
\hline $\begin{array}{l}\text { Average Û-value * } \\
\qquad\left(\mathrm{W} / \mathrm{m}^{2} \mathrm{~K}\right)\end{array}$ & 2.12 & 2.23 & 1.89 & 2.54 \\
\hline Compactness (m) & 1.57 & 1.33 & 3.46 & 2.96 \\
\hline $\mathrm{Uw}\left(\mathrm{W} / \mathrm{m}^{2} \mathrm{~K}\right)$ & 2.7 & 3.6 & 5.65 & 5.7 \\
\hline $\begin{array}{c}\text { Windows per Wall } \\
\text { Orientation }(\%)\end{array}$ & $\begin{array}{c}\mathrm{N}: 30 \\
\mathrm{~W}: 22.7 \\
\mathrm{~S}: 26\end{array}$ & $\begin{array}{l}\text { NW: } 8 \\
\text { SE: } 8\end{array}$ & $\begin{array}{l}\mathrm{N}: 16 \\
\mathrm{~S}: 16\end{array}$ & $\begin{array}{l}\mathrm{N}: 6 \\
\mathrm{~S}: 12\end{array}$ \\
\hline
\end{tabular}

* Average U-value is the sum weighted by area of the U-values of walls, windows, roof, and slab-on-grade.

Table 2. Type of POS according to the climatic zone and type of reference building.

\begin{tabular}{ccccc}
\hline Climatic Zone & SFH17 & SFH13 & MFH4 & MFH1 \\
\hline W1S2 & POS1 & POS5 & POS9 & POS13 \\
W2S2 & POS2 & POS6 & POS10 & POS14 \\
W2S3 & POS3 & POS7 & POS11 & POS15 \\
W3S2 & POS4 & POS8 & POS12 & POS16 \\
\hline
\end{tabular}

In order to increase the accuracy of these POS and increase their applicability, another set of 16 pre-evaluated POS have been obtained for the combination of the same climates and the buildings spinned $90^{\circ}$, to have their main façades oriented in E-W instead of N-S orientations. These POS solutions have been called POSX spinned. Where the number $\mathrm{X}$ corresponds to the same number that the one in the Table 2 for the combination of a given building and climate.

The 16 preliminary POS have been evaluated in 13 different climates and 42 reference buildings, providing a total of 546 cases where the POS have been proven to perform properly. In this matrix (Figure 1), each combination of reference building and representative climate is assigned with the POS that provides the best performance for the building. Therefore, each POS has been assigned with a specific colour to differentiate at a glance in the matrix the different POSs. As explained before, this is a result of the HAPPEN project developed by the authors of the article [5] and its use is explained in the case study section.

This methodology has been implemented in an online tool [20] where the orientation of the building can be assimilated to a building with the main façades N-S or E-W oriented.

\section{Methodology Limitations}

There are some limitations derived from the calculations that have been carried out to obtain the POS:

1. The exact pre-evaluated POS has been obtained for 4 reference buildings and 4 reference climates.

2. The reference buildings have been considered in two orientations for the POS calculations: main façades oriented N-S, and E-W.

In order to evaluate the accuracy of the 32 POS when they are applied in different buildings (in terms of their typology or thermal characteristics), the authors have calculated how well the POS perform for a combination of 42 buildings and 13 climates. The results of this are reported in Figure 1, where the best POS is reported for each combination of building typology and climate. In Figure 2, the primary energy saving obtained implementing the 
best POS is showed. Analyzing these figures, it can be concluded that the energy savings for other combinations are as high as required for an optimal solution and, as a consequence, the POS make up a heuristic solution that can be applied to achieve the goals reflected in Figure 2.

\begin{tabular}{|c|c|c|c|c|c|c|c|c|c|c|c|c|c|}
\hline Building|Climates & w053 & w054 & W1S2 & W153 & W154 & w2so & W2S1 & W2S2 & W253 & w350 & W351 & W352 & W450 \\
\hline MFH1 & POS13 & POS14 & POS13 & POS14 & POS14 & POS14 & POS14 & POS14 & POS15 & POS15 & POS15 & POS16 & POS15 \\
\hline MFH2 & POS12 & POS9 & POS12 & POS5 & POS5 & POS5 & POS5 & POS5 & POS5 & POS5 & POS6 & POS5 & POS6 \\
\hline MFH3 & POS9 & POS11 & POS9 & POS11 & POS10 & POS10 & POS10 & POS10 & POS10 & POS10 & P0S12 & POS10 & POS10 \\
\hline MFH4 & POS14 & POS14 & POS14 & POS14 & POS14 & POS14 & POS14 & POS14 & POS14 & POS14 & POS14 & POS14 & POS14 \\
\hline MFH5 & POS9 & POS11 & POS10 & POS11 & POS10 & POS10 & POS10 & POS10 & POS10 & POS10 & POS10 & POS10 & POS10 \\
\hline MFH6 & POS9 & POS11 & POS10 & POS10 & POS11 & POS11 & POS10 & POS11 & POS11 & POS10 & POS10 & POS10 & POS10 \\
\hline MFH7 & POS9 & POS10 & POS10 & POS11 & POS12 & POS12 & POS12 & POS12 & POS12 & POS12 & POS10 & POS12 & POS11 \\
\hline MFH8 & POS9 & POS9 & POS9 & POS9 & POS12 & POS10 & POS10 & POS9 & POS10 & POS12 & POS10 & POS12 & POS10 \\
\hline MFH9 & POS9 & POS11 & POS9 & POS9 & POS10 & POS10 & POS10 & POS10 & POS10 & POS10 & POS10 & POS10 & POS10 \\
\hline MFH10 & POS14 & POS14 & POS15 & POS15 & POS15 & POS15 & POS15 & POS15 & POS14 & POS15 & POS15 & POS15 & POS15 \\
\hline MFH11 & POS12 & POS12 & POS12 & POS12 & POS6 & POS5 & POS6 & POS6 & POS6 & POS5 & POS5 & POS5 & POS5 \\
\hline MFH12 & POS3 & POS1 & POS1 & POS2 & POS4 & POS4 & POS4 & POS4 & POS4 & POS4 & POS4 & POS4 & POS 4 \\
\hline MFH13 & POS1 & POS2 & POS2 & POS2 & POS4 & POS4 & POS 4 & POS4 & POS4 & POS4 & POS4 & POS4 & POS 4 \\
\hline MFH14 & POS9 & POS10 & POS10 & POS 10 & POS10 & POS10 & POS10 & POS 10 & POS10 & POS10 & POS 10 & POS10 & POS10 \\
\hline MFH15 & POS9 & POS11 & POS9 & POS9 & POS12 & POS12 & POS 12 & POS9 & POS12 & POS12 & POS 12 & POS 12 & POS 12 \\
\hline MFH16 & POS1 & POS2 & POS3 & POS3 & POS4 & POS4 & POS4 & POS4 & POS4 & POS4 & POS4 & POS4 & POS4 \\
\hline MFH17 & POS1 & POS1 & POS1 & POS1 & POS4 & POS4 & POS 4 & POS4 & POS4 & POS4 & POS4 & POS4 & POS4 \\
\hline MFH18 & POS9 & POS9 & POS9 & POS9 & POS12 & POS12 & POS12 & POS12 & POS12 & POS12 & POS12 & POS12 & POS12 \\
\hline MFH19 & POS9 & POS12 & POS12 & POS12 & POS 11 & POS11 & POS11 & POS11 & POS11 & POS11 & POS 10 & POS10 & POS10 \\
\hline MFHZO & POS1 & POS2 & POS1 & POS3 & POS4 & POS4 & POS 4 & POS4 & POS4 & POS4 & POS 4 & POS4 & POS4 \\
\hline MFH21 & POS9 & POS12 & POS9 & POS9 & POS12 & POS12 & POS12 & POS12 & POS12 & POS12 & POS12 & POS12 & POS11 \\
\hline SFH1 & POS5 & POS5 & POS5 & POS5 & POS5 & POS5 & POS5 & POS5 & POS5 & POS5 & POS5 & POS5 & POS5 \\
\hline SFHR & POS12 & POS12 & P0512 & POS12 & POS5 & POS5 & POS5 & POS5 & POS5 & POS5 & POS5 & POS5 & POS5 \\
\hline$S F H B$ & POS1 & POS1 & POS1 & POS1 & POS4 & POS4 & POS4 & POS4 & POS4 & POS4 & POS4 & POS4 & POS4 \\
\hline SFHA & POS12 & POS12 & POS7 & POS7 & POS5 & POS5 & POS5 & POS5 & POS5 & POS5 & POS5 & POS5 & POS5 \\
\hline SFHS & POS12 & POS 12 & POS5 & POS5 & POS5 & POS5 & POS5 & POS5 & POS5 & POS5 & POS5 & POS5 & POS5 \\
\hline SFHE & POS12 & POS12 & POS12 & POS 12 & POS5 & POS5 & POS5 & POS5 & POS5 & POS5 & POS5 & POS5 & POS5 \\
\hline SFHP & POS1 & POS1 & POS1 & POS1 & POS2 & POS4 & POS 4 & POS2 & POS4 & POS4 & POS4 & POS4 & POS4 \\
\hline SFHB & POS1 & POS2 & POS2 & POS2 & POS4 & POS4 & POS4 & POS4 & POS4 & POS4 & POS4 & POS4 & POS4 \\
\hline SFHO & POS1 & POS1 & POS1 & POS1 & POS4 & POS4 & POS4 & POS4 & POS4 & POS4 & POS4 & POS4 & POS4 \\
\hline SFH10 & POS1 & POS2 & POS2 & POS2 & POS4 & POS4 & POS4 & POS4 & POS4 & POS4 & POS4 & POS4 & POS 4 \\
\hline SFH11 & POS12 & POS 12 & POS5 & POS5 & POS5 & POS5 & POS5 & POS5 & POS5 & POS5 & POS5 & POS5 & POS5 \\
\hline SFH12 & POS12 & POS12 & POS12 & POS12 & POS5 & POS5 & POS5 & POS5 & POS5 & POS5 & POS5 & POS5 & POS5 \\
\hline SFH13 & POS5 & POS5 & POS6 & POS6 & POS6 & POS6 & POS6 & POS6 & POS5 & POS5 & POS6 & POS5 & POS5 \\
\hline SFH14 & POS12 & POS 12 & POS12 & POS12 & POS5 & POS6 & POS6 & POS5 & POS6 & POS6 & POS6 & POS6 & POS6 \\
\hline SFH15 & POS12 & POS12 & POS12 & POS12 & POS5 & POS5 & POS5 & POS5 & POS5 & POS5 & POS5 & POS5 & POS5 \\
\hline SFH16 & POS9 & POS9 & POS9 & POS9 & POS12 & POS12 & POS 12 & POS12 & POS12 & POS11 & POS11 & POS12 & POS11 \\
\hline SFH17 & POS9 & POS12 & POS9 & POS12 & POS12 & POS12 & POS12 & POS12 & POS12 & POS11 & POS11 & POS12 & POS11 \\
\hline SFH18 & POS12 & POS12 & P0S12 & POS12 & POS5 & POS5 & POS5 & POS5 & POS5 & POS5 & PO56 & POS5 & POS6 \\
\hline SFH19 & POS13 & POS14 & POS14 & POS14 & POS14 & POS15 & POS15 & POS14 & POS15 & POS15 & POS14 & POS14 & POS15 \\
\hline SFH2O & POS7 & POS5 & POS5 & POS5 & POS5 & POS5 & POS5 & POS5 & POS5 & POS5 & POS5 & POS5 & POS5 \\
\hline SFH21 & POS1 & POS1 & POS1 & POS1 & POS4 & POS4 & POS4 & POS4 & POS4 & POS4 & POS4 & POS4 & POS 4 \\
\hline
\end{tabular}

Figure 1. Full set of Packages of Optimal Solutions.

The advantage of this methodology consists in the fact that providing a building typology and a climate, an optimal solution in terms of LCC is suggested. The accuracy of the solution has been evaluated in terms of its performance in terms of the energy savings and the results have been satisfactory. The main limitation is that it could be very difficult to find a building similar to the one that is going to be refurbished. The possibility of the previous has been reduced by defining properly the 42 buildings using previous reference buildings derived from other studies such as the Episcope-Tabula project [21] and gathering data from the HAPPEN project partners.

The application in this study is totally correct, because the typology of the buildings SFH1, 2, 3 and MFH1, 2, 3 exactly corresponds to the one of the reference buildings that can be found in the Valencian Community due to the participation of IVE and EVha in the HAPPEN project. For further details of the thermal and geometrical characteristics of these buildings, Appendix B can be consulted. 


\begin{tabular}{|c|c|c|c|c|c|c|c|c|c|c|c|c|c|}
\hline Building|Climates & wos3 & wos4 & W1S2 & W1S3 & W1S4 & W2SO & W2S1 & W2S2 & W2S3 & W3SO & W3S1 & W3S2 & W4SO \\
\hline MFH1 & $26 \%$ & $35 \%$ & $41 \%$ & $42 \%$ & $43 \%$ & $54 \%$ & $54 \%$ & $45 \%$ & $43 \%$ & $54 \%$ & $52 \%$ & $49 \%$ & $53 \%$ \\
\hline MFH2 & $34 \%$ & $16 \%$ & $48 \%$ & $22 \%$ & $26 \%$ & $46 \%$ & $40 \%$ & $34 \%$ & $35 \%$ & $48 \%$ & $44 \%$ & $42 \%$ & $48 \%$ \\
\hline MFH3 & $31 \%$ & $36 \%$ & $31 \%$ & $43 \%$ & $44 \%$ & $56 \%$ & $56 \%$ & $53 \%$ & $51 \%$ & $58 \%$ & $56 \%$ & $55 \%$ & $55 \%$ \\
\hline MFH4 & $44 \%$ & $44 \%$ & $61 \%$ & $57 \%$ & $55 \%$ & $68 \%$ & $66 \%$ & $66 \%$ & $70 \%$ & $64 \%$ & $65 \%$ & $65 \%$ & $65 \%$ \\
\hline MFH5 & $26 \%$ & $34 \%$ & $42 \%$ & $43 \%$ & $44 \%$ & $61 \%$ & $60 \%$ & $55 \%$ & $55 \%$ & $63 \%$ & $60 \%$ & $60 \%$ & $60 \%$ \\
\hline MFH6 & $22 \%$ & $29 \%$ & $33 \%$ & $32 \%$ & $36 \%$ & $48 \%$ & $49 \%$ & $44 \%$ & $43 \%$ & $53 \%$ & $51 \%$ & $50 \%$ & $52 \%$ \\
\hline MFH7 & $40 \%$ & $41 \%$ & $45 \%$ & $50 \%$ & $50 \%$ & $64 \%$ & $64 \%$ & $59 \%$ & $59 \%$ & $65 \%$ & $62 \%$ & $62 \%$ & $62 \%$ \\
\hline MFH8 & $37 \%$ & $34 \%$ & $43 \%$ & $41 \%$ & $47 \%$ & $61 \%$ & $59 \%$ & $40 \%$ & $55 \%$ & $65 \%$ & $63 \%$ & $62 \%$ & $63 \%$ \\
\hline MFH9 & $14 \%$ & $24 \%$ & $30 \%$ & $29 \%$ & $34 \%$ & $59 \%$ & $57 \%$ & $48 \%$ & $49 \%$ & $62 \%$ & $59 \%$ & $57 \%$ & $60 \%$ \\
\hline MFH1O & $41 \%$ & $46 \%$ & $63 \%$ & $57 \%$ & $55 \%$ & $66 \%$ & $66 \%$ & $66 \%$ & $62 \%$ & $67 \%$ & $64 \%$ & $65 \%$ & $64 \%$ \\
\hline MFH11 & $39 \%$ & $43 \%$ & $58 \%$ & $55 \%$ & $31 \%$ & $50 \%$ & $45 \%$ & $41 \%$ & $40 \%$ & $52 \%$ & $46 \%$ & $46 \%$ & $49 \%$ \\
\hline MFH12 & $11 \%$ & $20 \%$ & $30 \%$ & $30 \%$ & $41 \%$ & $57 \%$ & $56 \%$ & $52 \%$ & $50 \%$ & $59 \%$ & $56 \%$ & $55 \%$ & $58 \%$ \\
\hline MFH13 & $29 \%$ & $40 \%$ & $54 \%$ & $49 \%$ & $51 \%$ & $61 \%$ & $59 \%$ & $60 \%$ & $55 \%$ & $62 \%$ & $59 \%$ & $59 \%$ & $60 \%$ \\
\hline MFH14 & $22 \%$ & $33 \%$ & $45 \%$ & $43 \%$ & $43 \%$ & $57 \%$ & $55 \%$ & $54 \%$ & $50 \%$ & $58 \%$ & $58 \%$ & $55 \%$ & $58 \%$ \\
\hline MFH15 & $22 \%$ & $31 \%$ & $32 \%$ & $30 \%$ & $38 \%$ & $43 \%$ & $43 \%$ & $41 \%$ & $41 \%$ & $43 \%$ & $43 \%$ & $43 \%$ & $42 \%$ \\
\hline MFH16 & $38 \%$ & $43 \%$ & $57 \%$ & $53 \%$ & $53 \%$ & $69 \%$ & $66 \%$ & $63 \%$ & $62 \%$ & $70 \%$ & $66 \%$ & $66 \%$ & $68 \%$ \\
\hline MFH17 & $31 \%$ & $28 \%$ & $39 \%$ & $37 \%$ & $50 \%$ & $72 \%$ & $68 \%$ & $62 \%$ & $62 \%$ & $72 \%$ & $69 \%$ & $68 \%$ & $71 \%$ \\
\hline MFH18 & $28 \%$ & $25 \%$ & $31 \%$ & $31 \%$ & $44 \%$ & $58 \%$ & $57 \%$ & $54 \%$ & $52 \%$ & $59 \%$ & $60 \%$ & $57 \%$ & $59 \%$ \\
\hline MFH19 & $47 \%$ & $51 \%$ & $70 \%$ & $66 \%$ & $65 \%$ & $76 \%$ & $76 \%$ & $76 \%$ & $72 \%$ & $77 \%$ & $75 \%$ & $76 \%$ & $75 \%$ \\
\hline MFH2O & $32 \%$ & $38 \%$ & $39 \%$ & $50 \%$ & $53 \%$ & $71 \%$ & $69 \%$ & $64 \%$ & $62 \%$ & $73 \%$ & $68 \%$ & $68 \%$ & $68 \%$ \\
\hline MFH21 & $34 \%$ & $41 \%$ & $32 \%$ & $34 \%$ & $47 \%$ & $51 \%$ & $52 \%$ & $52 \%$ & $49 \%$ & $52 \%$ & $55 \%$ & $51 \%$ & $53 \%$ \\
\hline SFH1 & $24 \%$ & $26 \%$ & $35 \%$ & $32 \%$ & $32 \%$ & $39 \%$ & $37 \%$ & $37 \%$ & $35 \%$ & $39 \%$ & $\mathbf{3 7} \%$ & $37 \%$ & $38 \%$ \\
\hline SFH2 & $46 \%$ & $46 \%$ & $59 \%$ & $55 \%$ & $27 \%$ & $39 \%$ & $36 \%$ & $33 \%$ & $33 \%$ & $41 \%$ & $37 \%$ & $37 \%$ & $39 \%$ \\
\hline SFH3 & $26 \%$ & $22 \%$ & $29 \%$ & $29 \%$ & $36 \%$ & $47 \%$ & $45 \%$ & $42 \%$ & $40 \%$ & $49 \%$ & $47 \%$ & $44 \%$ & $48 \%$ \\
\hline SFH4 & $45 \%$ & $47 \%$ & $41 \%$ & $36 \%$ & $38 \%$ & $48 \%$ & $46 \%$ & $45 \%$ & $42 \%$ & $49 \%$ & $46 \%$ & $46 \%$ & $47 \%$ \\
\hline SFH5 & $28 \%$ & $32 \%$ & $24 \%$ & $22 \%$ & $25 \%$ & $39 \%$ & $36 \%$ & $33 \%$ & $32 \%$ & $40 \%$ & $37 \%$ & $37 \%$ & $39 \%$ \\
\hline SFH6 & $29 \%$ & $32 \%$ & $37 \%$ & $36 \%$ & $24 \%$ & $36 \%$ & $33 \%$ & $28 \%$ & $30 \%$ & $37 \%$ & $35 \%$ & $34 \%$ & $37 \%$ \\
\hline SFH7 & $34 \%$ & $31 \%$ & $39 \%$ & $38 \%$ & $45 \%$ & $55 \%$ & $55 \%$ & $54 \%$ & $51 \%$ & $57 \%$ & $55 \%$ & $54 \%$ & $55 \%$ \\
\hline SFH8 & $44 \%$ & $44 \%$ & $55 \%$ & $\mathbf{5 0 \%}$ & $50 \%$ & $53 \%$ & $54 \%$ & $58 \%$ & $50 \%$ & $54 \%$ & $50 \%$ & $51 \%$ & $49 \%$ \\
\hline SFHS & $34 \%$ & $30 \%$ & $40 \%$ & $37 \%$ & $42 \%$ & $50 \%$ & $50 \%$ & $50 \%$ & $45 \%$ & $52 \%$ & $48 \%$ & $48 \%$ & $47 \%$ \\
\hline SFH10 & $40 \%$ & $43 \%$ & $52 \%$ & $47 \%$ & $56 \%$ & $57 \%$ & $57 \%$ & $59 \%$ & $56 \%$ & $57 \%$ & $56 \%$ & $57 \%$ & $56 \%$ \\
\hline SFH11 & $52 \%$ & $54 \%$ & $49 \%$ & $48 \%$ & $55 \%$ & $54 \%$ & $53 \%$ & $52 \%$ & $56 \%$ & $56 \%$ & $54 \%$ & $54 \%$ & $54 \%$ \\
\hline SFH12 & $43 \%$ & $45 \%$ & $54 \%$ & $53 \%$ & $40 \%$ & $48 \%$ & $46 \%$ & $45 \%$ & $44 \%$ & $49 \%$ & $47 \%$ & $46 \%$ & $47 \%$ \\
\hline SFH13 & $42 \%$ & $45 \%$ & $57 \%$ & $56 \%$ & $56 \%$ & $61 \%$ & $61 \%$ & $61 \%$ & $49 \%$ & $47 \%$ & $46 \%$ & $46 \%$ & $47 \%$ \\
\hline SFH14 & $42 \%$ & $43 \%$ & $53 \%$ & $51 \%$ & $37 \%$ & $49 \%$ & $47 \%$ & $43 \%$ & $44 \%$ & $49 \%$ & $47 \%$ & $47 \%$ & $48 \%$ \\
\hline SFH15 & $34 \%$ & $37 \%$ & $46 \%$ & $44 \%$ & $30 \%$ & $43 \%$ & $40 \%$ & $36 \%$ & $37 \%$ & $46 \%$ & $43 \%$ & $42 \%$ & $45 \%$ \\
\hline SFH16 & $48 \%$ & $45 \%$ & $57 \%$ & $54 \%$ & $60 \%$ & $68 \%$ & $65 \%$ & $67 \%$ & $62 \%$ & $69 \%$ & $67 \%$ & $68 \%$ & $67 \%$ \\
\hline SFH17 & $49 \%$ & $53 \%$ & $56 \%$ & $63 \%$ & $61 \%$ & $70 \%$ & $67 \%$ & $68 \%$ & $65 \%$ & $70 \%$ & $69 \%$ & $70 \%$ & $68 \%$ \\
\hline SFH18 & $36 \%$ & $40 \%$ & $51 \%$ & $48 \%$ & $28 \%$ & $42 \%$ & $39 \%$ & $34 \%$ & $35 \%$ & $44 \%$ & $41 \%$ & $39 \%$ & $44 \%$ \\
\hline SFH19 & $61 \%$ & $63 \%$ & $71 \%$ & $67 \%$ & $66 \%$ & $67 \%$ & $67 \%$ & $68 \%$ & $65 \%$ & $67 \%$ & $66 \%$ & $66 \%$ & $65 \%$ \\
\hline SFH2O & $40 \%$ & $46 \%$ & $58 \%$ & $54 \%$ & $53 \%$ & $58 \%$ & $58 \%$ & $58 \%$ & $68 \%$ & $75 \%$ & $72 \%$ & $72 \%$ & $74 \%$ \\
\hline SFH21 & $40 \%$ & $36 \%$ & $44 \%$ & $41 \%$ & $50 \%$ & $53 \%$ & $53 \%$ & $55 \%$ & $50 \%$ & $54 \%$ & $50 \%$ & $52 \%$ & $50 \%$ \\
\hline
\end{tabular}

Figure 2. Percentage of energy savings regarding the validated POS for each reference building and climate combination.

\section{Case study: Social Housing Stock Managed by EVha \\ 3.1. Introduction}

The aim of this article is to test the replicability of HAPPEN considerations all over other social dwellings managed by EVha in the Valencian Community (Figure 3), that joined this European project due to its condition of public social dwelling sort of curator. Actually, the fact of managing nowadays more than 14,000 flats all over the Valencian Community (Figure 4) drew its potential into the project Consortium. Thus, these first lines shall show a general overview on EVha's main task, i.e., the maintenance of a huge number of social dwellings as a public entity depending on the public regional administration.

First of all, a brief description of EVha as public entity is required. It procures the maintenance of the regional, public administration dwellings as well as the promotion of new housing developments. As a part of the regional ministry of Architecture, EVha depend on public funds related to annual budget lines in order to develop the interventions on social dwelling previously approved by the entity executive board. EVha operates on the three Valencian Community provinces such as Alicante, Castellón and Valencia. Therefore, being very appropriate to test the MedZEB approach.

EVha dwelling management covers currently more than 14,000 dwellings concerning the three provinces, with similar figures for Alicante and Valencia as the main part of the enhancement and a few of them in Castellón. This is the smallest in size, number of interventions, and population. 


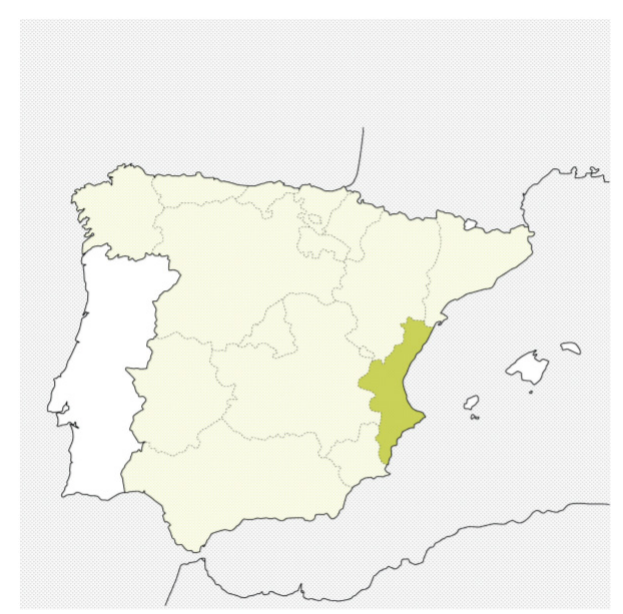

Figure 3. Location of Valencian Community in Spain.

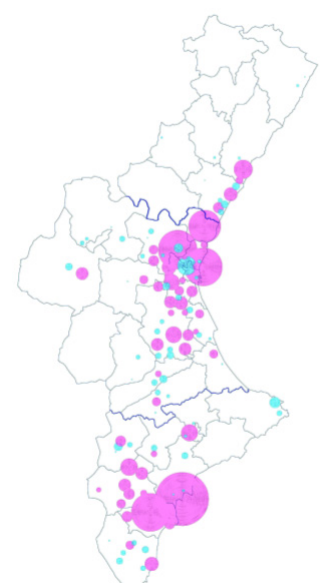

Figure 4. Social dwellings' location.

3.2. Characterisation of the Public Residential Building Stock in COMUNITAT Valenciana Region

The main features for the analysis of the pursued replicability of HAPPEN research on the social buildings stock are the number of blocks in every promotion group, their height in terms of number of floors, their age, building typology, and specifically the main orientation North-South or East-West. Only as a guidance, the number of flats per block is also shown in Table 3.

Table 3. EVha's building stock summary.

\begin{tabular}{|c|c|c|c|c|c|c|c|c|c|c|c|c|c|c|c|c|c|}
\hline & \multicolumn{4}{|c|}{ Blocks } & \multicolumn{3}{|c|}{ Dwellings } & \multicolumn{2}{|c|}{ SFH2 } & \multicolumn{2}{|c|}{ SFH3 } & \multicolumn{2}{|c|}{ MFH1 } & \multicolumn{2}{|c|}{ MFH2 } & \multicolumn{2}{|c|}{ MFH3 } \\
\hline & $\underset{\left(\mathrm{m}^{2}\right)}{\mathrm{S}_{\mathrm{TOTAL}}}$ & Total & $\begin{array}{l}\text { Number } \\
\text { N-S }\end{array}$ & E-W & $\mathbf{N}^{\circ}$ & $\mathrm{N}-\mathrm{S}$ & $E-W$ & N-S & N-S & E-W & N-S & N-S & E-W & N-S & E-W & N-S & E-W \\
\hline ALICANTE & $609,478.83$ & 1649 & 1172 & 477 & 9940 & 505 & 149 & 114 & 171 & 1 & - & 189 & 86 & 362 & 71 & 1 & - \\
\hline W1S2 & $609,478.83$ & 1649 & 1172 & 477 & 9940 & 505 & 149 & 114 & 171 & 1 & - & 189 & 86 & 362 & 71 & 1 & - \\
\hline W2S2 & - & - & - & - & - & - & - & - & - & - & - & - & - & - & - & - & - \\
\hline CATELLÓN & $232,439.00$ & 321 & 205 & 116 & 3271 & - & - & 18 & 16 & - & - & 108 & 48 & 79 & 51 & - & 1 \\
\hline W1S2 & $230,656.70$ & 308 & 205 & 103 & 3245 & - & - & 18 & 3 & - & - & 108 & 48 & 79 & 51 & - & 1 \\
\hline W2S2 & 1782.30 & 13 & 0 & 13 & 26 & - & - & - & 13 & - & - & - & - & - & - & - & - \\
\hline VALENCIA & $1,436,680.63$ & 2349 & 1663 & 686 & 22,360 & 571 & 9 & 7 & 22 & - & - & 685 & 436 & 397 & 205 & 9 & 8 \\
\hline W1S2 & $1,385,584.00$ & 1968 & 1300 & 668 & 21,519 & 229 & 3 & 7 & 22 & - & - & 682 & 435 & 379 & 194 & 9 & 8 \\
\hline W2S2 & $51,096.63$ & 381 & 363 & 18 & 841 & 342 & 6 & - & - & - & - & 3 & 1 & 18 & 11 & - & - \\
\hline VALENCIAN & & & & & & & & & & & & & & & & & \\
\hline $\begin{array}{l}\text { COMMU- } \\
\text { NITY }\end{array}$ & $2,278,598.46$ & 4319 & 3040 & 1279 & 35,571 & 1076 & 158 & 139 & 209 & 1 & - & 982 & 570 & 838 & 327 & 10 & 9 \\
\hline W1S2 & $2,225,719.53$ & 3925 & 1505 & 771 & 34,704 & 734 & 152 & 139 & 196 & 1 & - & 979 & 569 & 820 & 316 & 10 & 9 \\
\hline W2S2 & $52,878.93$ & 394 & 363 & 31 & 867 & 342 & 6 & - & 13 & - & - & 3 & 1 & 18 & 11 & - & - \\
\hline
\end{tabular}

* Useful area. 
The online tool [20] that uses the methodology described in Section 2 has been used to calculate the different Packages of Optimal Solutions according to the type of buildings (SFH1, SFH2, SFH3, MFH1, MFH2, MFH3) and climatic zone (W1S2, W2S2) existing in Comunitat Valenciana region (Section 3). There, the type of buildings has been classified according to the year of construction (Table 4):

Table 4. Building's classification according to the year of construction *

\begin{tabular}{ccc}
\hline$<\mathbf{1 9 8 0}$ & $\mathbf{1 9 8 0 - 2 0 0 0}$ & $>\mathbf{2 0 0 0}$ \\
\hline 1 & 2 & 3 \\
\hline * This is the classification for the buildings in Spain.
\end{tabular}

The buildings have also been classified according to their number of floors (Table 5):

Table 5. Building's classification according to the number of floors.

\begin{tabular}{cc}
\hline$\leq 2$ & $\geq 3$ \\
\hline SFH & MFH \\
\hline
\end{tabular}

Therefore, the types of buildings in Comunitat Valenciana region are SFH1, SFH2, SFH3, MFH1, MFH2, and MFH3.

For each group of buildings, with the same classification, orientation, and reference climate, the useful area has been calculated (Table 6).

Table 6. Total useful area of each building typology in the public residential building stock $\left(\mathrm{m}^{2}\right)$.

\begin{tabular}{|c|c|c|c|c|c|c|c|c|c|c|c|c|}
\hline & \multicolumn{2}{|c|}{ SFH1 } & \multicolumn{2}{|c|}{ SFH2 } & \multicolumn{2}{|c|}{ SFH3 } & \multicolumn{2}{|c|}{ MFH1 } & \multicolumn{2}{|c|}{ MFH2 } & \multicolumn{2}{|c|}{ MFH3 } \\
\hline & N-S & E-W & N-S & E-W & N-S & $E-W$ & N-S & E-W & N-S & E-W & N-S & E-W \\
\hline W1S2 & $92,065.23$ & $14,469.53$ & $11,996.64$ & $15,532.48$ & 180.00 & 0.00 & $734,134.71$ & $405,714.68$ & $677,794.59$ & $310,200.14$ & 9490.47 & 3940.10 \\
\hline W2S2 & $25,139.37$ & 409.99 & 0.00 & 1782.30 & 0.00 & 0.00 & 881.60 & 110.20 & $14,707.20$ & 9965.41 & 0.00 & 0.00 \\
\hline
\end{tabular}

Due to history, the ownership of the dwellings has been varying along time. Currently, some of all the flats built by the administration have a private entitlement, almost the half. It happened because some policies in former times offered the possibility to amortize the dwelling by the acceptation of their previous rents as a part of the purchase. That is why the total number of dwellings considered in the analysis exceed the current number of public dwellings managed by EVha. However, the global figures considered in this article are useful in terms of both the existing construction analysis and the further constructive implementation.

On the other hand, the main studied feature of the buildings is their orientation and location as well. Two main orientations have been considered: North-South and East-West, hereinafter referred to as N-S and E-W, respectively. As an advance, most of the blocks studied lay in a N-S orientation of the dwellings, near $70 \%$.

Concerning the location of the dwelling blocks, HAPPEN takes into consideration a whole Europe climate area mapping where the Valencian Community is affected by two of them. These are W1S2 and W2S2 related to the characterisation on the type of winters and summers. The Valencian territory is divided in two sections. The coolest of them is in a very small area in NW of Valencia and Western Castellón, corresponding to W2S2 area, and characterised by near continental weather with cold winters and hot summers. The rest of the region lays on the W1S2 area with not very cold winters and hot summers: coastal Castellón province, the rest of Valencian one and the whole Alicante one. This division is one of the points on the general analysis of the intended replication too.

There is no comment on the part of the dwelling surface because the usable area for every public social dwelling is $90 \mathrm{~m}^{2}$ due to the Spanish legislation. Only in a few numbers of flats, the usable area may reach $120 \mathrm{~m}^{2}$, which is devoted to large family cases. 


\subsection{Block Consideration}

Attending to a general overview on the number of flats, and due to the historical matters commented, the study covers the total number of promotions historically managed by EVha even those that were amortized. Apart from the more than 14,000 dwellings in EVha management, a total number of 35,571 dwellings have been studied for the analysis. Attending to provinces, around 60\% lay in Valencia, 30\% in Alicante, and only $10 \%$ in Castellón.

The first global approach of the buildings concerns their physical definition in blocks. The different buildings have been considered taking into account the physical location in the city, the height of the building and the orientation. For instance, when a building was composed of different heights (number of floors), for the purpose of this study, they have been considered as different building blocks. In other cases, the orientation of the flat may change such as in an L-shaped building or a flat at the endpoint of the building. In many cases, the conception of "block" has been closely related to that of "staircase", due to those possible changes of height, ground-floor use, orientation, or other variations in the linear, entire blocks.

\subsection{Block Location}

About the geographical distribution of the blocks, there are a total number of 4319 blocks grouping the 35,571 dwellings. More than $54 \%$ of them lay in Valencia province, followed by Alicante with $28 \%$, and finally Castellón with only $8 \%$ of the Community blocks.

Concerning the climate areas considered, almost $91 \%$ of the blocks lay in the W1S2 area, the biggest, coastal one, and the remaining 9\% lay on the W2S2 area, the inner and smallest mountain one-territorial distribution figures accordingly expected in terms of the size of the climate areas in the regional territory. These figures about blocks are substantially altered concerning the number of flats, because only $2.44 \%$ of the dwellings are located in the W2S2 climatic area, while $97.56 \%$ of the flats lay in the W1S2 area.

\subsection{Block Orientation}

This is one of the main remarkable features in the analysis considering the two principal orientations previously mentioned as N-S and E-W. Many of the flats belong to groups of independent buildings that originated new areas in the outskirts of the cities. In this case, many of the blocks were intentionally oriented and have a strictly North-South or, specifically, East-West orientation. As previously indicated, sometimes the orientation produces the difference among adjacent dwellings in the same building, like in the case of the extreme flats of a long, isolated block. Just a simple 90-degree spin in the orientation makes totally different the final comfort and habitation conditions in adjacent dwellings.

Concerning the orientation, almost $71 \%$ of the blocks have a North-South direction, and a little more than $29 \%$ the perpendicular East-West one. According to provinces, Valencia has very similar figures, Alicante has $72 \%$ and $28 \%$, respectively, and Castellón, in the $64 \%$ and $36 \%$ figures. As shown, the main orientation all over the blocks is North-South, against the generally accepted criterion of the best East-West flat orientation for ventilation and sunlight topics.

\subsection{Block Height}

The height of the blocks is closely related to their age and typology, which leads to the HAPPEN classification of types considered. All the blocks studied have been appointed to one of the four HAPPEN typologies previously defined. In general figures for the regional territory, almost $37 \%$ of the blocks belong to a single-family house, referred to as two-storey high buildings. The remaining $63 \%$ refer to multifamily houses, the more common type in the Mediterranean city.

Attending to the provinces, the proportions between single family and multifamily houses are $57 \%$ and $43 \%$ in Alicante, $11 \%$ and $89 \%$ in Castellón, and $26 \%$ and $74 \%$ in 
Valencia, respectively. As shown, the northern the block, the highest the building, but other specific considerations such as municipality or location into it should be considered.

\subsection{Block Typology}

Concerning previous distribution of the block in height, within that $37 \%$, more than $78 \%$ were built before 1980, where this single-family house typology was very often constructed, and the remaining $22 \%$ were built until 2000 , with only one block since then. Concerning the $63 \%$ of multifamily houses, almost the $57 \%$ of them were built before 1980 , almost the $42 \%$ until 200 , and only 19 blocks- $0.37 \%$ - after 2000 . Similar figures occur by provinces separately.

In a general overview, the bulk of block typology correspond to multifamily houses built before 2000 in the Valencia province. This case can be extended, in fewer numbers, to Alicante, and finally, in Castellón as a reflection of the regional trend.

This has been a quick review on the profile of the blocks at any time managed by EVha, as an available set of dwelling groups to introduce the possible replicability of HAPPEN methodology and requirements from now onwards.

As a summary of the figures mentioned previously, the table with all the figures is provided itemizing typologies, orientations, and number of blocks by province and for the whole of the Valencian Community (Table 3).

\section{Results and Discussion}

\subsection{Packages of Optimal Solutions Assigned to Comunitat Valenciana Buildings}

Figure 1 showed the Package of Optimal Solution that can be assigned to a type of building depending on the climatic zone. For instance, POS5 is the optimal preliminary Package of Optimal solutions for the SFH1 in the reference climate W1S2 and W2S2. In fact, in Figure 1, it can be appreciated that POS5 is the optimal preliminary POS for SHF1 in all the reference climates. Furthermore, if the building does not have the same orientation than the reference building, it has been selected the spinned option in the tool. Therefore, applying the matrix in Figure 1 to all the reference buildings (considering their orientation) and climates in Comunitat Valenciana, the POS1, POS1 spinned, POS4, POS4 spinned, POS5, POS5 spinned, POS9, POS10, POS10 spinned, POS12, POS12 spinned, POS13, POS13 spinned, POS14, and POS14 spinned (Table 7) have been run in the tool in order to obtain the solution that reaches the highest energy savings.

Table 7. POS according to the type of building and orientation, and climate zone in Comunitat Valenciana region.

\begin{tabular}{|c|c|c|c|c|c|c|c|c|c|c|c|c|}
\hline & \multicolumn{2}{|c|}{ SFH1 } & \multicolumn{2}{|c|}{ SFH2 } & \multicolumn{2}{|c|}{ SFH3 } & \multicolumn{2}{|c|}{ MFH1 } & \multicolumn{2}{|c|}{ MFH2 } & \multicolumn{2}{|c|}{ MFH3 } \\
\hline & N-S & E-W & N-S & E-W & N-S & E-W & N-S & E-W & N-S & E-W & N-S & E-W \\
\hline W1S2 & POS5 & $\begin{array}{c}\text { POS5 } \\
\text { spinned }\end{array}$ & POS12 & $\begin{array}{l}\text { POS12 } \\
\text { spinned }\end{array}$ & POS1 & $\begin{array}{c}\text { POS1 } \\
\text { spinned }\end{array}$ & POS13 & $\begin{array}{l}\text { POS13 } \\
\text { spinned }\end{array}$ & POS12 & $\begin{array}{c}\text { POS12 } \\
\text { spinned }\end{array}$ & POS9 & $\begin{array}{c}\text { POS9 } \\
\text { spinned }\end{array}$ \\
\hline W2S2 & POS5 & $\begin{array}{l}\text { POS5 } \\
\text { spinned }\end{array}$ & POS5 & $\begin{array}{c}\text { POS5 } \\
\text { spinned }\end{array}$ & POS4 & $\begin{array}{l}\text { POS4 } \\
\text { spinned }\end{array}$ & POS14 & $\begin{array}{l}\text { POS14 } \\
\text { spinned }\end{array}$ & POS5 & $\begin{array}{c}\text { POS5 } \\
\text { spinned }\end{array}$ & POS10 & $\begin{array}{l}\text { POS10 } \\
\text { spinned }\end{array}$ \\
\hline
\end{tabular}

Due to the fact that one of the input data of the tool [20] was the type of reference building with its orientation, it was necessary to characterise all the building stock as it has been done in Section 3. This way, the group of buildings that are coincident in the reference climate, type of reference building and orientation, can be renovated with the same Package of Optimal Solutions.

\subsection{Potential of Energy Savings in Terms of Primary Energy Per Year $(M W / h)$}

To obtain the energy savings for each of the POS (Table 7), it has to be defined in the tool the climatic zone, the energy cost for the country, the reference building, spinned (if the main façades are orientated differently to the reference building), the interest rate, 
inflation, and years. In the case of POS1, W1S2 and the reference building located in Cyprus (Figure 5).

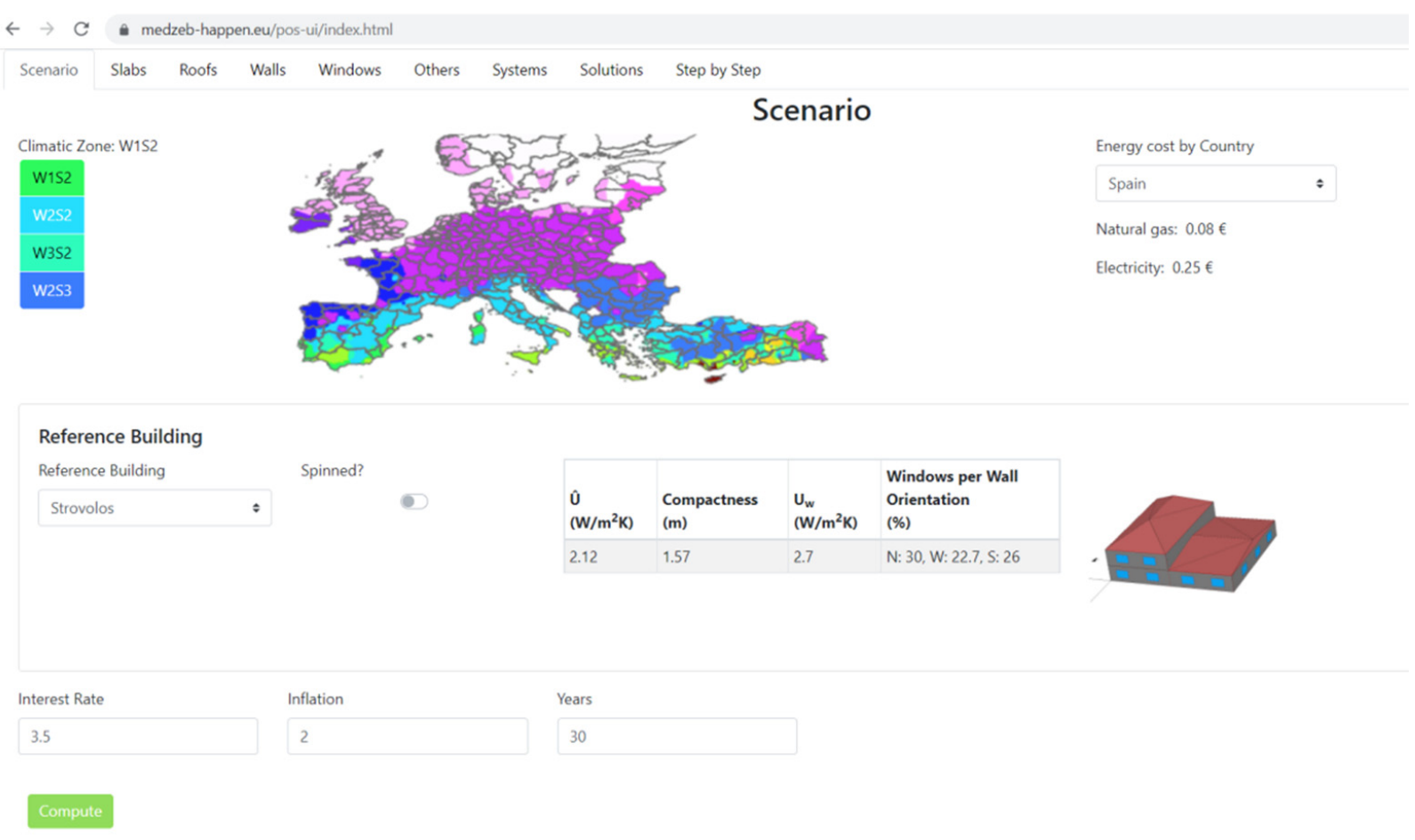

Figure 5. POS1 Scenario.

For the different constructive elements (slabs, roofs, etc.), what can be changed is the cost $\left(€ / \mathrm{m}^{2}\right)$. Moreover, different systems for heating, cooling, and domestic hot water can be chosen.

For the purpose of this study, the energy costs of Spain apply, and the interest rate of $3.5 \%$ and inflation of $2 \%$ are fixed values for all the cases. It has been selected 30 years as described in the LCC calculation [5].

The aim of the paper was to analyse the potential for reducing global consumption. For the reference heating system, the different performances can be seen in the Appendix B table [22]. Using this value, the final energy consumption has been evaluated. The transition from final to primary energy has been made using a factor of 1.01 kWhp.e./kWhf.e. This value is the one reported for Spain in [23]. For the reference cooling system, the procedure is analogous, the energy source is electricity, and its average efficiency or seasonal energy efficiency ratio is shown in Appendix B; the transfer factor

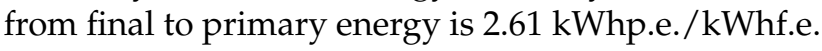

The thermal systems have not been considered for the renovation since EVha manages public housing stock where passive measures for improving the building envelope are prioritized to active measures [6,7]. Therefore, further energy savings could be obtained if they are considered in the renovation.

After selecting the mentioned parameters to obtain POS1 in the tool, the representative global values for each solution are summarized in Table 8.

The energy needs of the building in its initial situation are the following:

Heating energy needs: $44.22 \mathrm{kWh} / \mathrm{m}^{2}$.

Cooling energy needs: $21.28 \mathrm{kWh} / \mathrm{m}^{2}$.

DHW energy needs: $16.23 \mathrm{kWh} / \mathrm{m}^{2}$, they are not relevant for the identification of the optimal as the renovation measures does not concern this energy need.

The primary energy consumption (current situation) is $99.78\left(\mathrm{~kW} / \mathrm{h} \mathrm{m}^{2}\right)$.

The final energy consumption (current situation) is $72.33\left(\mathrm{kWh} / \mathrm{m}^{2}\right)$.

The $\mathrm{CO}_{2}$ emissions in its initial situation are $19.49 \mathrm{~kg} / \mathrm{m}^{2}$. 
Table 8. POS 1 results.

\begin{tabular}{|c|c|c|c|c|c|c|c|c|c|c|c|}
\hline$\dot{\mathbf{z}}$ & 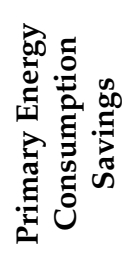 & 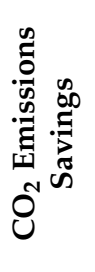 & 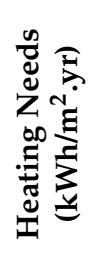 & 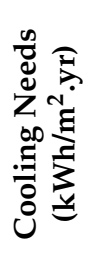 & 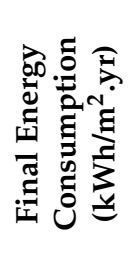 & 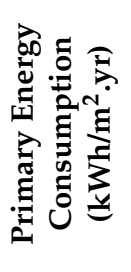 &  & 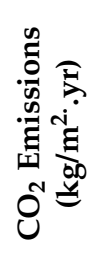 & 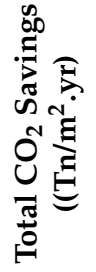 & 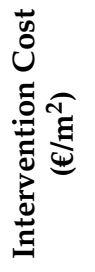 & $\underbrace{\infty}_{0}$ \\
\hline 1 & $55 \%$ & $57 \%$ & 13.68 & 6.92 & 33.97918 & 44.95 & 0.055 & 8.47 & 0.011 & 43.58 & 123.31 \\
\hline 2 & $57 \%$ & $58 \%$ & 12.41 & 6.60 & 32.52172 & 43.00 & 0.057 & 8.10 & 0.011 & 48.79 & 125.07 \\
\hline 3 & $60 \%$ & $61 \%$ & 9.54 & 7.04 & 29.80872 & 40.04 & 0.060 & 7.65 & 0.012 & 53.54 & 125.49 \\
\hline 4 & $58 \%$ & $59 \%$ & 10.54 & 7.22 & 30.91404 & 41.47 & 0.058 & 7.91 & 0.012 & 51.68 & 126.11 \\
\hline 5 & $61 \%$ & $61 \%$ & 9.10 & 6.97 & 29.32284 & 39.41 & 0.060 & 7.53 & 0.012 & 55.77 & 126.63 \\
\hline 6 & $62 \%$ & $63 \%$ & 8.28 & 6.70 & 28.35493 & 38.09 & 0.062 & 7.27 & 0.012 & 58.76 & 127.20 \\
\hline 7 & $53 \%$ & $54 \%$ & 15.19 & 7.25 & 35.67641 & 47.18 & 0.053 & 8.89 & 0.011 & 43.57 & 127.26 \\
\hline 8 & $60 \%$ & $61 \%$ & 9.28 & 6.88 & 29.46658 & 39.53 & 0.060 & 7.54 & 0.012 & 56.90 & 127.84 \\
\hline 9 & $62 \%$ & $63 \%$ & 7.85 & 6.62 & 27.87673 & 37.47 & 0.062 & 7.16 & 0.012 & 60.99 & 128.34 \\
\hline 10 & $55 \%$ & $56 \%$ & 13.90 & 6.93 & 34.20142 & 45.22 & 0.055 & 8.52 & 0.011 & 48.79 & 128.98 \\
\hline 11 & $58 \%$ & $59 \%$ & 10.96 & 7.40 & 31.43692 & 42.21 & 0.058 & 8.06 & 0.011 & 53.54 & 129.36 \\
\hline 12 & $56 \%$ & $57 \%$ & 11.98 & 7.57 & 32.56981 & 43.67 & 0.056 & 8.33 & 0.011 & 51.67 & 130.03 \\
\hline
\end{tabular}

For the purpose of this study, it was the priority to obtain the highest primary energy savings (\%). In some cases, there are different solutions that get the same primary energy and $\mathrm{CO}_{2}$ savings; therefore, it was prioritised to choose the one with less Primary Energy Consumption $\left(\mathrm{kWh} / \mathrm{m}^{2} \cdot \mathrm{yr}\right)$, even if the differences are quite small. For example, solution 9 has been chosen for POS 1. It is composed of the following renovation measures (Table 9):

Table 9. POS1: Renovation measures of solution 9.

\begin{tabular}{|c|c|c|c|}
\hline Element & Description & $\begin{array}{c}\text { Thermal } \\
\text { Characteristics }\end{array}$ & Inv. Cost \\
\hline External wall & $\begin{array}{c}\text { Internal Air Chamber } \\
\text { Insulation with } 5 \mathrm{~cm} \\
\text { of Rock Wool }\end{array}$ & $\begin{array}{l}\mathrm{R}=1.47 \mathrm{~m}^{2} \cdot \mathrm{K} / \mathrm{W} \\
\mathrm{U}=0.34 \mathrm{~W} / \mathrm{m}^{2} \cdot \mathrm{K}\end{array}$ & $14.88 € / \mathrm{m}^{2}$ \\
\hline Roof & $\begin{array}{l}\text { External Insulation } \\
\text { with } 12 \mathrm{~cm} \text { of XPS }\end{array}$ & $\mathrm{R}=3.75 \mathrm{~m}^{2} \cdot \mathrm{K} / \mathrm{W}$ & $37.29 € / \mathrm{m}^{2}$ \\
\hline Windows & \multicolumn{3}{|c|}{ No Replacement Required in the Cost Optimal context } \\
\hline Slab & \multicolumn{3}{|c|}{ No Replacement Required in the Cost Optimal context } \\
\hline Thermal bridges $(\mathrm{TB})$ & $\begin{array}{c}\text { Insulation with PUR } \\
\text { injected } 2 \mathrm{~cm} \text { in all TB } \\
\text { to reduce them at } \\
40-50 \%+\text { go to } 0.05 \\
\mathrm{~W} / \mathrm{mK} \text { in the } \\
\text { Glazings }\end{array}$ & $\begin{array}{c}\text { Thermal } \\
\text { Conductivity: } \\
0.05 \mathrm{~W} / \mathrm{mK} \\
\text { Linear Thermal } \\
\text { Transmittance } \\
\text { (window): } 0.95 \\
\mathrm{~W} / \mathrm{mK}\end{array}$ & $15.27 € / 1 . \mathrm{m}$ \\
\hline Ventilation & \multicolumn{3}{|c|}{ No Replacement Required in the Cost Optimal context } \\
\hline Shading elements & Overhang-vertical 50 & Solar factor $=0.29$ & $90 € / \mathrm{m}^{2}$ \\
\hline Airtightness & \multicolumn{3}{|c|}{ No Replacement Required in the Cost Optimal context } \\
\hline
\end{tabular}

The composition of the renovation measures of all the selected solutions can be consulted on the tables of Appendix A.

This process has been followed to obtain the results of all the POS applicable to the building stock of the study (Table 10). 
Table 10. Selected solutions from the results of all the POS applicable to the building stock.

\begin{tabular}{|c|c|c|c|c|c|c|c|c|}
\hline ڤ & 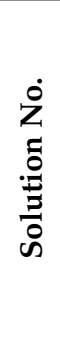 &  &  & 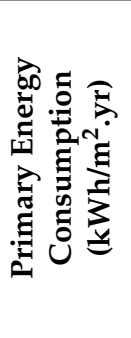 & 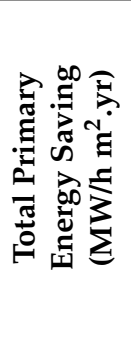 & 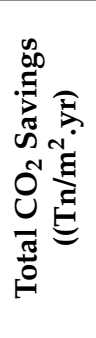 & 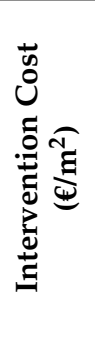 & 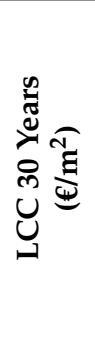 \\
\hline 1 & 9 & $62 \%$ & $63 \%$ & 37.47 & 0.062 & 0.012 & 60.99 & 128.34 \\
\hline $1 s^{*}$ & 6 & $59 \%$ & $60 \%$ & 43.01 & 0.061 & 0.012 & 58.76 & 135.23 \\
\hline 4 & 1 & 65 & 65 & 80.79 & 0.149 & 0.026 & 78.82 & 211.02 \\
\hline $4 s^{*}$ & 4 & 68 & 66 & 74.13 & 0.159 & 0.027 & 78.82 & 207.60 \\
\hline 5 & 6 & 53 & 50 & 51.27 & 0.057 & 0.010 & 63.07 & 156.37 \\
\hline $5 s *$ & 3 & 39 & 38 & 65.98 & 0.043 & 0.008 & 44.71 & 160.82 \\
\hline 9 & 3 & 41 & 42 & 36.75 & 0.026 & 0.005 & 24.96 & 88.89 \\
\hline $9 \mathrm{~s} *$ & 7 & 48 & 49 & 36.65 & 0.033 & 0.007 & 32.44 & 96.72 \\
\hline 10 & 5 & 65 & 63 & 33.26 & 0.061 & 0.011 & 58.20 & 115.81 \\
\hline $10 \mathrm{~s} *$ & 2 & 69 & 66 & 30.95 & 0.069 & 0.012 & 24.71 & 81.94 \\
\hline 12 & 11 & 70 & 70 & 44.51 & 0.106 & 0.018 & 62.25 & 135.66 \\
\hline $12 \mathrm{~s} *$ & 7 & 73 & 70 & 42.12 & 0.112 & 0.018 & 39.41 & 115.63 \\
\hline 13 & 8 & 57 & 54 & 47.16 & 0.061 & 0.011 & 59.14 & 145.40 \\
\hline $13 \mathrm{~s}$ * & 4 & 47 & 45 & 47.16 & 0.041 & 0.007 & 59.14 & 145.40 \\
\hline 14 & 8 & 45 & 45 & 69.59 & 0.057 & 0.010 & 76.71 & 195.93 \\
\hline $14 s^{*}$ & 10 & 40 & 39 & 75.73 & 0.051 & 0.009 & 76.71 & 206.68 \\
\hline
\end{tabular}

Once the solutions that provided the higher energy savings for each of the POS were selected, the results were applied to the whole building stock.

To do so, it was necessary to obtain the useful area for each group of buildings that were characterised as explained in Section 3 per type of reference building, orientation and reference climate. The primary energy consumption per year $\left(\mathrm{MW} / \mathrm{h} \cdot \mathrm{m}^{2}\right)$ of the selected solution within a POS was applied to the useful area $\left(\mathrm{m}^{2}\right)$ of the corresponding group of buildings. As a result, the primary energy consumption per year of the current building stock is $288,054.83 \mathrm{MW} / \mathrm{h}$ (Table 11).

Table 11. Primary energy consumption per year (MW/h) in the current status of the building stock.

\begin{tabular}{ccccccccccccc}
\hline & \multicolumn{2}{c}{ SFH1 } & \multicolumn{2}{c}{ SFH2 } & \multicolumn{2}{c}{ SFH3 } & \multicolumn{2}{c}{ MFH1 } & \multicolumn{2}{c}{ MFH2 } & \multicolumn{2}{c}{ MFH3 } \\
\hline & N-S & E-W & N-S & E-W & N-S & E-W & N-S & E-W & N-S & E-W & N-S & E-W \\
\hline W1S2 & $10,042.95$ & 1565.08 & 1779.90 & 2423.07 & 17.75 & - & $80,515.80$ & $36,100.95$ & $100,562.12$ & $48,391.22$ & 591.14 & 277.70 \\
W2S2 & 2742.33 & 44.35 & - & 192.78 & - & - & 111.55 & 13.91 & 1604.34 & 1077.90 & - & - \\
\hline
\end{tabular}

The total primary energy savings per year that could be reached if the buildings were renovated are 180,495.13 $\mathrm{MW} / \mathrm{h}$ (Table 12).

Table 12. Total primary energy savings per year (MW/h) of $100 \%$ of EVha building stock.

\begin{tabular}{ccccccccccccc}
\hline & \multicolumn{2}{c}{ SFH1 } & \multicolumn{2}{c}{ SFH2 } & \multicolumn{2}{c}{ SFH3 } & \multicolumn{2}{c}{ MFH1 } & \multicolumn{2}{c}{ MFH2 } & \multicolumn{2}{c}{ MFH3 } \\
\hline & N-S & E-W & N-S & E-W & N-S & E-W & N-S & E-W & N-S & E-W & N-S & E-W \\
\hline W1S2 & 5266.13 & 621.47 & 1273.87 & 1732.45 & 11.21 & 0.00 & $45,014.69$ & $16,772.92$ & $71,971.74$ & $34,598.80$ & 242.71 & 131.70 \\
W2S2 & 1437.97 & 17.61 & 0.00 & 76.55 & 0.00 & 0.00 & 50.41 & 5.62 & 841.25 & 428.01 & 0.00 & 0.00 \\
\hline
\end{tabular}

However, this would correspond to the best-case scenario, which is $100 \%$ of the building stock is renovated. Currently, on average, less than $1 \%$ of the national building stock is renovated each year in Europe [1], meaning that over 1804.95 MW/h of primary energy savings are reached (Table 13). 
Table 13. Total primary energy savings per year (MW/h) of $1 \%$ of EVha building stock.

\begin{tabular}{cccccccccccccc}
\hline & \multicolumn{2}{c}{ SFH1 } & \multicolumn{2}{c}{ SFH2 } & \multicolumn{2}{c}{ SFH3 } & \multicolumn{2}{c}{ MFH1 } & \multicolumn{2}{c}{ MFH2 } & MFH3 \\
\hline & N-S & E-W & N-S & E-W & N-S & E-W & N-S & E-W & N-S & E-W & N-S & E-W \\
\hline W1S2 & 52.66 & 6.21 & 12.74 & 17.32 & 0.11 & 0.00 & 450.15 & 167.73 & 719.72 & 345.99 & 2.43 & 1.32 \\
W2S2 & 14.38 & 0.18 & 0.00 & 0.77 & 0.00 & 0.00 & 0.50 & 0.06 & 8.41 & 4.28 & 0.00 & 0.00 \\
\hline
\end{tabular}

As indicated previously, in order to meet climate and energy objectives, the current rates of renovations of buildings should at least double. Thus, it has been considered the scenario with $2 \%$ of the dwellings being renovated and getting as a result $3609.90 \mathrm{MW} / \mathrm{h}$ of primary energy savings (Table 14).

Table 14. Total primary energy savings per year $(\mathrm{MW} / \mathrm{h})$ of $2 \%$ of EVha building stock.

\begin{tabular}{ccccccccccccc}
\hline & \multicolumn{2}{c}{ SFH1 } & \multicolumn{2}{c}{ SFH2 } & \multicolumn{2}{c}{ SFH3 } & \multicolumn{2}{c}{ MFH1 } & \multicolumn{2}{c}{ MFH2 } & \multicolumn{2}{c}{ MFH3 } \\
\hline & N-S & E-W & N-S & E-W & N-S & E-W & N-S & E-W & N-S & E-W & N-S & E-W \\
\hline W1S2 & 105.32 & 12.43 & 25.48 & 34.65 & 0.22 & 0.00 & 900.29 & 335.46 & 1439.43 & 691.98 & 4.85 & 2.63 \\
W2S2 & 28.76 & 0.35 & 0.00 & 1.53 & 0.00 & 0.00 & 1.01 & 0.11 & 16.83 & 8.56 & 0.00 & 0.00 \\
\hline
\end{tabular}

\section{Conclusions}

The impact of the renovations of a building stock has been analysed in Valencian Community. For the renovation scenarios, the solutions were selected from a Package of Optimal Solutions for a refence building located in a reference climate. These solutions are optimal, because they were obtained applying Optimal Renovation Strategies through Life-Cycle Analysis [5] and implemented in the online tool previously introduced [20].

It is possible to adopt the described methodology to extend the potential of energy savings to a specific context, where implementing the renovation. Following the definition of buildings' classification of interest, the main façades orientation and the packages of optimal solutions represent a replicable approach to tailor the potential of energy savings of the building stock across Mediterranean countries in Europe.

It should be noted that, for the purpose of this study, some parameters were fixed (the interest rate, inflation, and the number of years for LCC). However, the tool allows to change them and obtain the result according to each specific case.

Furthermore, the prices of the different constructive elements could be adapted to the specific context. In the present paper, the default values were kept since they were obtained from the database of construction prices in the Valencian Community [24].

The thermal systems have not been considered for the renovation (the default values were kept), so that higher energy savings could be obtained if they are considered in the renovation. Therefore, further research including the renovation measures in the variability of the thermal systems should be carried out to get higher energy savings.

The annual energy savings per year in the $100 \%$ renovation scenario would be equal to the $63 \%$ of the present annual energy consumption of the whole building stock.

Author Contributions: Conceptualization, C.I.J.E. and M.N.E.; methodology, C.I.J.E. and J.M.S.L.; validation, J.M.S.L., M.N.E. and M.F.F.; investigation, C.I.J.E.; data curation, C.I.J.E. and C.D.M.G.; formal analysis, M.N.E. and M.F.F.; writing - original draft preparation, C.I.J.E. and C.D.M.G.; writingreview and editing, J.M.S.L.; supervision, J.M.S.L. All authors have read and agreed to the published version of the manuscript.

Funding: This research was funded by European Union's Horizon 2020 research and innovation programme, grant agreement number 785072. It has been performed within the framework of the project HAPPEN-Holistic APproach and Platform for the deep renovation of the med residential built Environment. It reflects only the author's view and that the Agency and the Commission are not responsible for any use that may be made of the information it contains. 
Institutional Review Board Statement: Not applicable.

Informed Consent Statement: Not applicable.

Data Availability Statement: Not applicable.

Conflicts of Interest: The authors declare no conflict of interest.

\section{Appendix A}

The following tables summarise per POS the thermal properties and price of the renovation measures that can be applied to the studied building stock. They include a description of the renovation per building constructive element, whether they exist or not, the thermal resistance or other thermal property, and the cost.

Table A1. POS1s: Renovation measures of solution 6

\begin{tabular}{|c|c|c|c|}
\hline Element & Description & Thermal Characteristics & Inv. Cost \\
\hline Façade & $\begin{array}{l}\text { Internal Air Chamber } \\
\text { Insulation with } 5 \mathrm{~cm} \text { of } \\
\text { Expanded Perlite }\end{array}$ & $\begin{array}{c}\mathrm{R}=1.16 \mathrm{~m}^{2} \cdot \mathrm{K} / \mathrm{W} \\
\mathrm{U}=0.043 \mathrm{~W} / \mathrm{m}^{2} \cdot \mathrm{K}\end{array}$ & $12.16 € / \mathrm{m}^{2}$ \\
\hline Roof & $\begin{array}{l}\text { External Insulation with } \\
12 \mathrm{~cm} \text { of XPS }\end{array}$ & $\mathrm{R}=3.75 \mathrm{~m}^{2} \cdot \mathrm{K} / \mathrm{W}$ & $37.29 € / \mathrm{m}^{2}$ \\
\hline Windows & No Replacement & - & - \\
\hline Slab & No Replacement & - & - \\
\hline Thermal bridges (TB) & $\begin{array}{c}\text { Insulation with panels } \\
\text { made of PUR injected } \\
2 \mathrm{~cm} \text { in all TB to reduce } \\
\text { them at } 40-50 \%+\text { go to } \\
0.05 \mathrm{~W} / \mathrm{mK} \text { in } \\
\text { the Glazings }\end{array}$ & $\begin{array}{c}\text { Thermal Conductivity: } \\
0.05 \mathrm{~W} / \mathrm{mK} \\
\text { Linear Thermal } \\
\text { Transmittance Reduction } \\
\text { (window): } 0.95 \mathrm{~W} / \mathrm{mK}\end{array}$ & $15.27 € / 1 . \mathrm{m}$ \\
\hline Ventilation & Controlled VMC & $\begin{array}{l}\text { Equivalent Air Flow [n air } \\
\text { change } / \mathrm{h}-\mathrm{m}^{3} / \mathrm{h} \text { ]: } 0.42\end{array}$ & $220.48 € / 100 \mathrm{~m}^{2}$ \\
\hline Shading elements & Overhang-vertical 50 & Solar factor $=0.29$ & $90 € / \mathrm{m}^{2}$ \\
\hline Airtightness & No improvement & - & - \\
\hline
\end{tabular}

Table A2. POS4: Renovation measures of solution 1.

\begin{tabular}{|c|c|c|c|}
\hline Element & Description & Thermal Characteristics & Inv. Cost \\
\hline External wall & $\begin{array}{l}\text { Internal Air Chamber } \\
\text { Insulation with } 5 \mathrm{~cm} \text { of } \\
\text { Rock Wool }\end{array}$ & $\begin{array}{l}\mathrm{R}=1.47 \mathrm{~m}^{2} \cdot \mathrm{K} / \mathrm{W} \\
\mathrm{U}=0.34 \mathrm{~W} / \mathrm{m}^{2} \cdot \mathrm{K}\end{array}$ & $14.88 € / \mathrm{m}^{2}$ \\
\hline Roof & $\begin{array}{l}\text { External Insulation with } \\
12 \mathrm{~cm} \text { of XPS }\end{array}$ & $\mathrm{R}=3.75 \mathrm{~m}^{2} \cdot \mathrm{K} / \mathrm{W}$ & $37.29 € / \mathrm{m}^{2}$ \\
\hline Windows & No Replacement & - & - \\
\hline Slab & No Replacement & - & - \\
\hline Thermal bridges (TB) & $\begin{array}{l}\text { Insulation with PUR } \\
\text { injected } 2 \mathrm{~cm} \text { in all TB to } \\
\text { reduce them at } 40-50 \%+ \\
\text { go to } 0.05 \mathrm{~W} / \mathrm{mK} \text { in } \\
\text { the Glazings }\end{array}$ & $\begin{array}{c}\text { Thermal Conductivity: } \\
0.05 \mathrm{~W} / \mathrm{mK} \\
\text { Linear Thermal } \\
\text { Transmittance (window): } \\
0.95 \mathrm{~W} / \mathrm{mK}\end{array}$ & $15.27 € / 1 . \mathrm{m}$ \\
\hline Ventilation & Controlled VMC & $\begin{array}{l}\text { Equivalent Air Flow [n air } \\
\left.\text { change } / \mathrm{h}-\mathrm{m}^{3} / \mathrm{h}\right]: 0.42\end{array}$ & $220.48 € / 100 \mathrm{~m}^{2}$ \\
\hline Shading elements & Overhang-vertical 50 & Solar factor $=0.29$ & $90 € / \mathrm{m}^{2}$ \\
\hline Airtightness & No improvement & - & - \\
\hline
\end{tabular}


Table A3. POS4s: Renovation measures of solution 4.

\begin{tabular}{cccc}
\hline Element & Description & Thermal Characteristics & Inv. Cost \\
\hline External wall & $\begin{array}{c}\text { Internal Air Chamber } \\
\text { Insulation with } 5 \mathrm{~cm} \text { of } \\
\text { Rock Wool }\end{array}$ & $\begin{array}{c}\mathrm{R}=1.47 \mathrm{~m}^{2} \cdot \mathrm{K} / \mathrm{W} \\
\mathrm{U}=0.34 \mathrm{~W} / \mathrm{m}^{2} \cdot \mathrm{K}\end{array}$ & $14.88 € / \mathrm{m}^{2}$ \\
\hline Roof & $\begin{array}{c}\text { External Insulation with } \\
12 \mathrm{~cm} \text { of XPS }\end{array}$ & $\mathrm{R}=3.75 \mathrm{~m}^{2} \cdot \mathrm{K} / \mathrm{W}$ & $37.29 € / \mathrm{m}^{2}$ \\
\hline Windows & No Replacement & - & - \\
\hline Slab & No Replacement & - & - \\
Thermal bridges (TB) & $\begin{array}{c}\text { Insulation with PUR } \\
\text { injected 2 cm in all TB to } \\
\text { reduce them at 40-50\% }\end{array}$ & $\begin{array}{c}\text { Thermal Conductivity: } \\
0.09 \mathrm{~W} / \mathrm{mK} \\
\text { Linear Thermal } \\
\text { Perimeter: } 50 \% ; \text { window: } 0 \%\end{array}$ & $15.26 € / 1 . \mathrm{m}$. \\
\hline Ventilation & Controlled VMC & $\begin{array}{c}\text { Equivalent Air Flow [n air } \\
\left.\text { change } / \mathrm{h}-\mathrm{m}^{3} / \mathrm{h}\right]: 0.42\end{array}$ & $220.48 € / 100 \mathrm{~m}^{2}$ \\
\hline Shading elements & Overhang-vertical 50 & Solar factor $=0.29$ & $90 € / \mathrm{m}^{2}$ \\
\hline Airtightness & No improvement & - & - \\
\hline
\end{tabular}

Table A4. POS5: Renovation measures of solution 6.

\begin{tabular}{|c|c|c|c|}
\hline Element & Description & Thermal Characteristics & Inv. Cost \\
\hline External wall & $\begin{array}{l}\text { Internal Air Chamber } \\
\text { Insulation with } 5 \mathrm{~cm} \text { of } \\
\text { Rock Wool }\end{array}$ & $\begin{array}{l}\mathrm{R}=1.47 \mathrm{~m}^{2} \cdot \mathrm{K} / \mathrm{W} \\
\mathrm{U}=0.34 \mathrm{~W} / \mathrm{m}^{2} \cdot \mathrm{K}\end{array}$ & $14.88 € / \mathrm{m}^{2}$ \\
\hline Roof & $\begin{array}{l}\text { External Insulation with } \\
5 \mathrm{~cm} \text { of XPS }\end{array}$ & $\mathrm{R}=1.47 \mathrm{~m}^{2} \cdot \mathrm{K} / \mathrm{W}$ & $10.25 € / \mathrm{m}^{2}$ \\
\hline Windows & No Replacement & - & - \\
\hline Slab & No Replacement & - & - \\
\hline Thermal bridges (TB) & $\begin{array}{l}\text { Insulation with PUR } \\
\text { injected } 2 \mathrm{~cm} \text { in all TB to } \\
\text { reduce them at } 40-50 \%\end{array}$ & $\begin{array}{c}\text { Thermal Conductivity: } \\
0.09 \mathrm{~W} / \mathrm{mK} \\
\text { Linear Thermal } \\
\text { Transmittance Reduction: } \\
\text { Perimeter: } 50 \% \text {; window: } 0 \%\end{array}$ & $15.26 € / 1 . \mathrm{m}$. \\
\hline Ventilation & Controlled VMC & $\begin{array}{l}\text { Equivalent Air Flow [n air } \\
\text { change } / \mathrm{h}-\mathrm{m}^{3} / \mathrm{h} \text { ]: } 0.42\end{array}$ & $220.48 € / 100 \mathrm{~m}^{2}$ \\
\hline Shading elements & No replacement & - & - \\
\hline Airtightness & No improvement & - & - \\
\hline
\end{tabular}

Table A5. POS5s: Renovation measures of solution 3.

\begin{tabular}{cccc}
\hline Element & Description & Thermal Characteristics & Inv. Cost \\
\hline External wall & $\begin{array}{c}\text { Internal Air Chamber } \\
\text { Insulation with } 3 \mathrm{~cm} \text { of } \\
\text { Expanded Perlite }\end{array}$ & $\begin{array}{c}\mathrm{R}=0.7 \mathrm{~m}^{2} \cdot \mathrm{K} / \mathrm{W} \\
\mathrm{U}=0.043 \mathrm{~W} / \mathrm{m}^{2} \cdot \mathrm{K}\end{array}$ & $9.29 € / \mathrm{m}^{2}$ \\
\hline Roof & $\begin{array}{c}\text { External Insulation with } \\
5 \mathrm{~cm} \text { of XPS }\end{array}$ & $\mathrm{R}=1.47 \mathrm{~m}^{2} \cdot \mathrm{K} / \mathrm{W}$ & $10.25 € / \mathrm{m}^{2}$ \\
\hline Windows & No Replacement & - & $13.30 € / \mathrm{m}^{2}$ \\
\hline Slab & $\begin{array}{c}\text { Insulation with } 4 \mathrm{~cm} \text { of } \\
\text { XPS or PU Panels }\end{array}$ & $\begin{array}{c}\mathrm{R}=1.43 \mathrm{~m}^{2} \cdot \mathrm{K} / \mathrm{W} \\
\mathrm{U}=0.028 \mathrm{~W} / \mathrm{m}^{2} \cdot \mathrm{K}\end{array}$ & $15.27 € / 1 . \mathrm{m}$. \\
\hline Thermal bridges (TB) & $\begin{array}{c}\text { Insulation with PUR } \\
\text { injected } 2 \mathrm{~cm} \text { in all TB to } \\
\text { reduce them at } 40-50 \%+ \\
\text { go to } 0.05 \mathrm{~W} / \mathrm{mK} \text { in } \\
\text { the Glazings }\end{array}$ & $\begin{array}{c}\text { Thermal Conductivity: } \\
0.05 \mathrm{~W} / \mathrm{mK} \\
\text { Linear Thermal }\end{array}$ & $\begin{array}{c}\text { Transmittance }(\text { window): } \\
0.95 \mathrm{~W} / \mathrm{mK}\end{array}$ \\
\hline
\end{tabular}


Table A5. Cont.

\begin{tabular}{cccc}
\hline Element & Description & Thermal Characteristics & Inv. Cost \\
\hline Ventilation & Controlled VMC & $\begin{array}{c}\text { Equivalent Air Flow }[\mathrm{n} \text { air } \\
\left.\text { change } / \mathrm{h}-\mathrm{m}^{3} / \mathrm{h}\right]: 0.42\end{array}$ & $220.48 € / 100 \mathrm{~m}^{2}$ \\
\hline Shading elements & No replacement & - & - \\
\hline Airtightness & No improvement & - & - \\
\hline
\end{tabular}

Table A6. POS9: Renovation measures of solution 3.

\begin{tabular}{cccc}
\hline Element & Description & Thermal Characteristics & Inv. Cost \\
\hline External wall & $\begin{array}{c}\text { Internal Air Chamber } \\
\text { Insulation with } 3 \mathrm{~cm} \text { of } \\
\text { Expanded Perlite }\end{array}$ & $\begin{array}{c}\mathrm{R}=0.7 \mathrm{~m}^{2} \cdot \mathrm{K} / \mathrm{W} \\
\mathrm{U}=0.043 \mathrm{~W} / \mathrm{m}^{2} \cdot \mathrm{K}\end{array}$ & $9.29 € / \mathrm{m}^{2}$ \\
\hline Roof & $\begin{array}{c}\text { External Insulation with } \\
12 \text { cm of XPS }\end{array}$ & $\mathrm{R}=3.75 \mathrm{~m}^{2} \cdot \mathrm{K} / \mathrm{W}$ & $37.29 € / \mathrm{m}^{2}$ \\
\hline Windows & $\begin{array}{c}\text { Double windows with } \\
\text { 2lasses with } 1.6 \mathrm{~cm} \text { of air } \\
\text { interspace. Frame of wood }\end{array}$ & $\begin{array}{c}\mathrm{U}_{\mathrm{F}}=1.43 \mathrm{~W} / \mathrm{m}^{2} \cdot \mathrm{K} \\
\mathrm{U}_{\mathrm{W}}=2.70 \mathrm{~W} / \mathrm{m}^{2} \cdot \mathrm{K}\end{array}$ & $116.17 € / \mathrm{m}^{2}$ \\
\hline Slab & $\begin{array}{c}\text { Insulation with } 4 \mathrm{~cm} \text { of } \\
\text { XPS or PU Panels }\end{array}$ & $\begin{array}{c}\mathrm{R}=1.43 \mathrm{~m}^{2} \cdot \mathrm{K} / \mathrm{W} \\
\mathrm{U}=0.028 \mathrm{~W} / \mathrm{m}^{2} \cdot \mathrm{K}\end{array}$ & $13.30 € / \mathrm{m}^{2}$ \\
\hline Thermal bridges (TB) & No improvement & - & - \\
\hline Ventilation & Controlled VMC & $\begin{array}{c}\text { Equivalent Air Flow }[\mathrm{n} \text { air } \\
\left.\text { change } / \mathrm{h}-\mathrm{m}^{3} / \mathrm{h}\right]: 0.42\end{array}$ & $220.48 € / 100 \mathrm{~m}^{2}$ \\
\hline Shading elements & Overhang-vertical 50 & Solar factor $=0.29$ & $90 € / \mathrm{m}^{2}$ \\
\hline Airtightness & No improvement & - & - \\
\hline
\end{tabular}

Table A7. POS9s: Renovation measures of solution 7.

\begin{tabular}{|c|c|c|c|}
\hline Element & Description & Thermal Characteristics & Inv. Cost \\
\hline External wall & $\begin{array}{l}\text { Internal Air Chamber } \\
\text { Insulation with } 3 \mathrm{~cm} \text { of } \\
\text { Expanded Perlite }\end{array}$ & $\begin{array}{c}\mathrm{R}=0.7 \mathrm{~m}^{2} \cdot \mathrm{K} / \mathrm{W} \\
\mathrm{U}=0.043 \mathrm{~W} / \mathrm{m}^{2} \cdot \mathrm{K}\end{array}$ & $9.29 € / \mathrm{m}^{2}$ \\
\hline Roof & $\begin{array}{l}\text { External Insulation with } \\
12 \mathrm{~cm} \text { of XPS }\end{array}$ & $\mathrm{R}=3.75 \mathrm{~m}^{2} \cdot \mathrm{K} / \mathrm{W}$ & $37.29 € / \mathrm{m}^{2}$ \\
\hline Windows & $\begin{array}{l}\text { Double windows with } \\
2 \text { glasses with low- } \varepsilon \text { with } \\
1.6 \mathrm{~cm} \text { of air interspace. } \\
\text { Frame of wood }\end{array}$ & $\begin{aligned} \mathrm{U}_{\mathrm{F}} & =1.43 \mathrm{~W} / \mathrm{m}^{2} \cdot \mathrm{K} \\
\mathrm{U}_{\mathrm{W}} & =1.40 \mathrm{~W} / \mathrm{m}^{2} \cdot \mathrm{K}\end{aligned}$ & $169.90 € / \mathrm{m}^{2}$ \\
\hline Slab & No Insulation & - & - \\
\hline Thermal bridges (TB) & $\begin{array}{l}\text { Insulation with PUR } \\
\text { injected } 2 \mathrm{~cm} \text { in all TB to } \\
\text { reduce them at } 40-50 \%\end{array}$ & $\begin{array}{c}\text { Thermal Conductivity: } \\
0.09 \mathrm{~W} / \mathrm{mK} \\
\text { Linear Thermal } \\
\text { Transmittance Reduction: } \\
\text { Perimeter: } 50 \% \text {; window: } 0 \%\end{array}$ & $15.26 € / 1 . \mathrm{m}$. \\
\hline Ventilation & Controlled VMC & $\begin{array}{l}\text { Equivalent Air Flow [n air } \\
\text { change } / \mathrm{h}-\mathrm{m}^{3} / \mathrm{h} \text { ]: } 0.42\end{array}$ & $220.48 € / 100 \mathrm{~m}^{2}$ \\
\hline Shading elements & Overhang-vertical 50 & Solar factor $=0.29$ & $90 € / \mathrm{m}^{2}$ \\
\hline Airtightness & No improvement & - & - \\
\hline
\end{tabular}


Table A8. POS10: Renovation measures of solution 5.

\begin{tabular}{|c|c|c|c|}
\hline Element & Description & Thermal Characteristics & Inv. Cost \\
\hline External wall & $\begin{array}{l}\text { Internal Air Chamber } \\
\text { Insulation with } 5 \mathrm{~cm} \text { of } \\
\text { Rock Wool }\end{array}$ & $\begin{array}{l}\mathrm{R}=1.47 \mathrm{~m}^{2} \cdot \mathrm{K} / \mathrm{W} \\
\mathrm{U}=0.34 \mathrm{~W} / \mathrm{m}^{2} \cdot \mathrm{K}\end{array}$ & $14.88 € / \mathrm{m}^{2}$ \\
\hline Roof & $\begin{array}{l}\text { External Insulation with } \\
12 \mathrm{~cm} \text { of XPS }\end{array}$ & $\mathrm{R}=3.75 \mathrm{~m}^{2} \cdot \mathrm{K} / \mathrm{W}$ & $37.29 € / \mathrm{m}^{2}$ \\
\hline Windows & $\begin{array}{l}\text { Double windows with } \\
2 \text { glasses window with } \\
\text { low- } \varepsilon \text { with } 1.6 \mathrm{~cm} \text { of air } \\
\text { interspace. Frame of PVC }\end{array}$ & $\begin{aligned} \mathrm{U}_{\mathrm{F}} & =1.3 \mathrm{~W} / \mathrm{m}^{2} \cdot \mathrm{K} \\
\mathrm{U}_{\mathrm{W}} & =1.4 \mathrm{~W} / \mathrm{m}^{2} \cdot \mathrm{K}\end{aligned}$ & $129.57 € / \mathrm{m}^{2}$ \\
\hline Slab & No Insulation & - & - \\
\hline Thermal bridges (TB) & $\begin{array}{l}\text { Insulation with PUR } \\
\text { injected } 2 \mathrm{~cm} \text { in all TB to } \\
\text { reduce them at } 40-50 \%\end{array}$ & $\begin{array}{c}\text { Thermal Conductivity: } \\
0.09 \mathrm{~W} / \mathrm{mK} \\
\text { Linear Thermal } \\
\text { Transmittance Reduction: } \\
\text { Perimeter: } 50 \% \text {; window: } 0 \%\end{array}$ & $15.26 € / 1 . \mathrm{m}$. \\
\hline Ventilation & Controlled VMC & $\begin{array}{l}\text { Equivalent Air Flow [n air } \\
\left.\text { change } / \mathrm{h}-\mathrm{m}^{3} / \mathrm{h}\right]: 0.42\end{array}$ & $220.48 € / 100 \mathrm{~m}^{2}$ \\
\hline Shading elements & Overhang-vertical 50 & Solar factor $=0.29$ & $90 € / \mathrm{m}^{2}$ \\
\hline Airtightness & $\begin{array}{l}\text { Soudal window system- } \\
\text { (RAL System for } \\
\text { airtightness) }\end{array}$ & $\mathrm{n} 50=3$ & $16 € / 1 . \mathrm{m}$ \\
\hline
\end{tabular}

Table A9. POS10s: Renovation measures of solution 2.

\begin{tabular}{|c|c|c|c|}
\hline Element & Description & Thermal Characteristics & Inv. Cost \\
\hline External wall & $\begin{array}{l}\text { Internal Air Chamber } \\
\text { Insulation with } 3 \mathrm{~cm} \text { of } \\
\text { Expanded Perlite }\end{array}$ & $\begin{array}{c}\mathrm{R}=0.7 \mathrm{~m}^{2} \cdot \mathrm{K} / \mathrm{W} \\
\mathrm{U}=0.043 \mathrm{~W} / \mathrm{m}^{2} \cdot \mathrm{K}\end{array}$ & $9.29 € / \mathrm{m}^{2}$ \\
\hline Roof & $\begin{array}{l}\text { Internal insulation with } \\
\qquad 4 \mathrm{~cm} \text { of Perlite }\end{array}$ & $\mathrm{R}=0.93 \mathrm{~m}^{2} \cdot \mathrm{K} / \mathrm{W}$ & $9.29 € / \mathrm{m}^{2}$ \\
\hline Windows & No Replacement & - & - \\
\hline Slab & $\begin{array}{l}\text { Insulation with } 2 \mathrm{~cm} \text { of } \\
\text { XPS or PU Panels }\end{array}$ & $\begin{array}{c}\mathrm{R}=0.71 \mathrm{~m}^{2} \cdot \mathrm{K} / \mathrm{W} \\
\mathrm{U}=0.028 \mathrm{~W} / \mathrm{m}^{2} \cdot \mathrm{K}\end{array}$ & $12.03 € / \mathrm{m}^{2}$ \\
\hline Thermal bridges (TB) & $\begin{array}{l}\text { Insulation with PUR } \\
\text { injected } 2 \mathrm{~cm} \text { in all TB to } \\
\text { reduce them at } 40-50 \%\end{array}$ & $\begin{array}{c}\text { Thermal Conductivity: } \\
0.09 \mathrm{~W} / \mathrm{mK} \\
\text { Linear Thermal } \\
\text { Transmittance Reduction: } \\
\text { Perimeter: } 50 \% \text {; window: } \%\end{array}$ & $15.26 € / 1 . \mathrm{m}$ \\
\hline Ventilation & No Replacement & - & - \\
\hline Shading elements & Overhang-vertical 50 & Solar factor $=0.29$ & $90 € / \mathrm{m}^{2}$ \\
\hline Airtightness & $\begin{array}{l}\text { Soudal window system- } \\
\text { (RAL System for } \\
\text { airtightness) }\end{array}$ & $\mathrm{n} 50=3$ & $16 € / 1 . \mathrm{m}$ \\
\hline
\end{tabular}

Table A10. POS12: Renovation measures of solution 11.

\begin{tabular}{|c|c|c|c|}
\hline Element & Description & Thermal Characteristics & Inv. Cost \\
\hline External wall & $\begin{array}{l}\text { External insulation with } \\
12 \mathrm{~cm} \text { of EPS }\end{array}$ & $\begin{array}{c}\mathrm{R}=3.3 \mathrm{~m}^{2} \cdot \mathrm{K} / \mathrm{W} \\
\mathrm{U}=0.036 \mathrm{~W} / \mathrm{m}^{2} \cdot \mathrm{K}\end{array}$ & $48.94 € / \mathrm{m}^{2}$ \\
\hline Roof & $\begin{array}{l}\text { External Insulation with } \\
12 \mathrm{~cm} \text { of XPS }\end{array}$ & $\mathrm{R}=3.75 \mathrm{~m}^{2} \cdot \mathrm{K} / \mathrm{W}$ & $37.29 € / \mathrm{m}^{2}$ \\
\hline Windows & $\begin{array}{l}\text { Double windows with } \\
2 \text { glasses window with } \\
\text { low- } \varepsilon \text { with } 1.6 \mathrm{~cm} \text { of air } \\
\text { interspace. Frame of PVC }\end{array}$ & $\begin{aligned} \mathrm{U}_{\mathrm{F}} & =1.3 \mathrm{~W} / \mathrm{m}^{2} \cdot \mathrm{K} \\
\mathrm{U}_{\mathrm{W}} & =1.4 \mathrm{~W} / \mathrm{m}^{2} \cdot \mathrm{K}\end{aligned}$ & $129.57 € / \mathrm{m}^{2}$ \\
\hline
\end{tabular}


Table A10. Cont

\begin{tabular}{cccc}
\hline Element & Description & Thermal Characteristics & Inv. Cost \\
\hline Slab & No Replacement & - & - \\
Thermal bridges (TB) & $\begin{array}{c}\text { Insulation with PUR } \\
\text { injected } 2 \mathrm{~cm} \text { in all TB to } \\
\text { reduce them at 40-50\% }+ \\
\text { go to 0.05 W/mK in } \\
\text { the Glazings }\end{array}$ & $\begin{array}{c}\text { Thermal Conductivity: } \\
0.05 \mathrm{~W} / \mathrm{mK} \\
\text { Linear Thermal } \\
\text { Transmittance (window): } \\
0.95 \mathrm{~W} / \mathrm{mK}\end{array}$ & $15.27 € /$ l.m. \\
Ventilation & Controlled VMC & $\begin{array}{c}\text { Equivalent Air Flow [n air } \\
\left.\text { change } / \mathrm{h}-\mathrm{m}^{3} / \mathrm{h}\right]: 0.42\end{array}$ & $220.48 € / 100 \mathrm{~m}^{2}$ \\
\hline Shading elements & Overhang-vertical 50 & Solar factor $=0.29$ & $90 € / \mathrm{m}^{2}$ \\
\hline Airtightness & No improvement & - & - \\
\hline
\end{tabular}

Table A11. POS12s: Renovation measures of solution 7.

\begin{tabular}{|c|c|c|c|}
\hline Element & Description & Thermal Characteristics & Inv. Cost \\
\hline External wall & $\begin{array}{l}\text { Internal Air Chamber } \\
\text { Insulation with } 3 \mathrm{~cm} \text { of } \\
\text { Expanded Perlite }\end{array}$ & $\begin{array}{c}\mathrm{R}=0.7 \mathrm{~m}^{2} \cdot \mathrm{K} / \mathrm{W} \\
\mathrm{U}=0.043 \mathrm{~W} / \mathrm{m}^{2} \cdot \mathrm{K}\end{array}$ & $9.29 € / \mathrm{m}^{2}$ \\
\hline Roof & $\begin{array}{l}\text { VR }(5 \mathrm{~cm} \text { air gap })+ \\
\text { External insulation with } \\
\text { XPS panels of } 8 \mathrm{~cm}\end{array}$ & $\mathrm{R}=2.42 \mathrm{~m}^{2} \cdot \mathrm{K} / \mathrm{W}$ & $14.45 € / \mathrm{m}^{2}$ \\
\hline Windows & $\begin{array}{c}\text { Double windows with } \\
2 \text { glasses with low- } \varepsilon \text { with } \\
1.6 \mathrm{~cm} \text { of air interspace. } \\
\text { Frame of wood }\end{array}$ & $\begin{aligned} \mathrm{U}_{\mathrm{F}} & =1.43 \mathrm{~W} / \mathrm{m}^{2} \cdot \mathrm{K} \\
\mathrm{U}_{\mathrm{W}} & =1.40 \mathrm{~W} / \mathrm{m}^{2} \cdot \mathrm{K}\end{aligned}$ & $169.90 € / \mathrm{m}^{2}$ \\
\hline Slab & $\begin{array}{l}\text { Insulation with } 10 \mathrm{~cm} \text { of } \\
\text { light-weighted cement } \\
\text { based with Vermiculite }\end{array}$ & $\begin{array}{l}\mathrm{R}=1.25 \mathrm{~m}^{2} \cdot \mathrm{K} / \mathrm{W} \\
\mathrm{U}=0.08 \mathrm{~W} / \mathrm{m}^{2} \cdot \mathrm{K}\end{array}$ & $46.70 € / \mathrm{m}^{2}$ \\
\hline Thermal bridges (TB) & No improvement & - & - \\
\hline Ventilation & Controlled VMC & $\begin{array}{l}\text { Equivalent Air Flow [n air } \\
\text { change } / \mathrm{h}-\mathrm{m}^{3} / \mathrm{h} \text { ]: } 0.42\end{array}$ & $220.48 € / 100 \mathrm{~m}^{2}$ \\
\hline Shading elements & No replacement & - & - \\
\hline Airtightness & No improvement & - & - \\
\hline
\end{tabular}

Table A12. POS13: Renovation measures of solution 8; and POS13s: Renovation measures of solution 4.

\begin{tabular}{|c|c|c|c|}
\hline Element & Description & Thermal Characteristics & Inv. Cost \\
\hline External wall & $\begin{array}{l}\text { Internal Air Chamber } \\
\text { Insulation with } 5 \mathrm{~cm} \text { of } \\
\text { Rock Wool }\end{array}$ & $\begin{array}{l}\mathrm{R}=1.47 \mathrm{~m}^{2} \cdot \mathrm{K} / \mathrm{W} \\
\mathrm{U}=0.34 \mathrm{~W} / \mathrm{m}^{2} \cdot \mathrm{K}\end{array}$ & $14.88 € / \mathrm{m}^{2}$ \\
\hline Roof & $\begin{array}{l}\text { External insulation with } \\
8 \mathrm{~cm} \text { of XPS }\end{array}$ & $\mathrm{R}=2.35 \mathrm{~m}^{2} \cdot \mathrm{K} / \mathrm{W}$ & $28.78 € / \mathrm{m}^{2}$ \\
\hline Windows & No Replacement & - & - \\
\hline Slab & No Replacement & - & - \\
\hline Thermal bridges (TB) & $\begin{array}{l}\text { Insulation with PUR } \\
\text { injected } 2 \mathrm{~cm} \text { in all TB to } \\
\text { reduce them at } 40 \%-50 \% \\
+ \text { go to } 0.05 \mathrm{~W} / \mathrm{mK} \text { in } \\
\text { the Glazings }\end{array}$ & $\begin{array}{c}\text { Thermal Conductivity: } \\
0.05 \mathrm{~W} / \mathrm{mK} \\
\text { Linear Thermal } \\
\text { Transmittance (window): } \\
0.95 \mathrm{~W} / \mathrm{mK}\end{array}$ & $15.27 € / 1 . \mathrm{m}$ \\
\hline Ventilation & Controlled VMC & $\begin{array}{l}\text { Equivalent Air Flow [n air } \\
\left.\text { change } / \mathrm{h}-\mathrm{m}^{3} / \mathrm{h}\right]: 0.42\end{array}$ & $220.48 € / 100 \mathrm{~m}^{2}$ \\
\hline Shading elements & Overhang-vertical 50 & Solar factor $=0.29$ & $90 € / \mathrm{m}^{2}$ \\
\hline Airtightness & $\begin{array}{l}\text { Soudal window system- } \\
\text { (RAL System for } \\
\text { airtightness) }\end{array}$ & $\mathrm{n} 50=3$ & $16 € / 1 . \mathrm{m}$ \\
\hline
\end{tabular}


Table A13. POS14: Renovation measures of solution 8; and POS14s: Renovation measures of solution 10.

\begin{tabular}{|c|c|c|c|}
\hline Element & Description & Thermal Characteristics & Inv. Cost \\
\hline External wall & $\begin{array}{l}\text { Internal Air Chamber } \\
\text { Insulation with } 5 \mathrm{~cm} \text { of } \\
\text { Rock Wool }\end{array}$ & $\begin{array}{l}\mathrm{R}=1.47 \mathrm{~m}^{2} \cdot \mathrm{K} / \mathrm{W} \\
\mathrm{U}=0.34 \mathrm{~W} / \mathrm{m}^{2} \cdot \mathrm{K}\end{array}$ & $14.88 € / \mathrm{m}^{2}$ \\
\hline Roof & $\begin{array}{l}\text { External insulation with } \\
5 \mathrm{~cm} \text { of XPS }\end{array}$ & $\mathrm{R}=1.47 \mathrm{~m}^{2} \cdot \mathrm{K} / \mathrm{W}$ & $24.49 € / \mathrm{m}^{2}$ \\
\hline Windows & No Replacement & - & - \\
\hline Slab & No Replacement & - & - \\
\hline Thermal bridges (TB) & $\begin{array}{l}\text { Insulation with PUR } \\
\text { injected } 2 \mathrm{~cm} \text { in all TB to } \\
\text { reduce them at } 40-50 \%\end{array}$ & $\begin{array}{c}\text { Thermal Conductivity: } \\
0.09 \mathrm{~W} / \mathrm{mK} \\
\text { Linear Thermal } \\
\text { Transmittance Reduction: } \\
\text { Perimeter: } 50 \% \text {; window: } \\
0 \%\end{array}$ & $15.26 € / 1 . \mathrm{m}$ \\
\hline Ventilation & $\begin{array}{c}\text { Controlled with thermal } \\
\text { exchange (Heat } \\
\text { Recovery System) }\end{array}$ & $\begin{array}{l}\text { Equivalent Air Flow [n air } \\
\text { change/h-m }{ }^{3} / \mathrm{h} \text { ]: } 0.24\end{array}$ & $5245.29 € / 100 \mathrm{~m}^{2}$ \\
\hline Shading elements & Overhang-vertical 50 & Solar factor $=0.29$ & $90 € / \mathrm{m}^{2}$ \\
\hline Airtightness & No improvement & - & - \\
\hline
\end{tabular}

\section{Appendix B}

The following table shows the U-values and the rest of thermal and geometrical characteristics used for the different referent buildings in the methodology described in the paper. 
Table A14. Thermal and geometrical characteristics for the reference buildings in Spain (SF1, SFH2, SFH3 and MFH1, MFH2, MFH3).

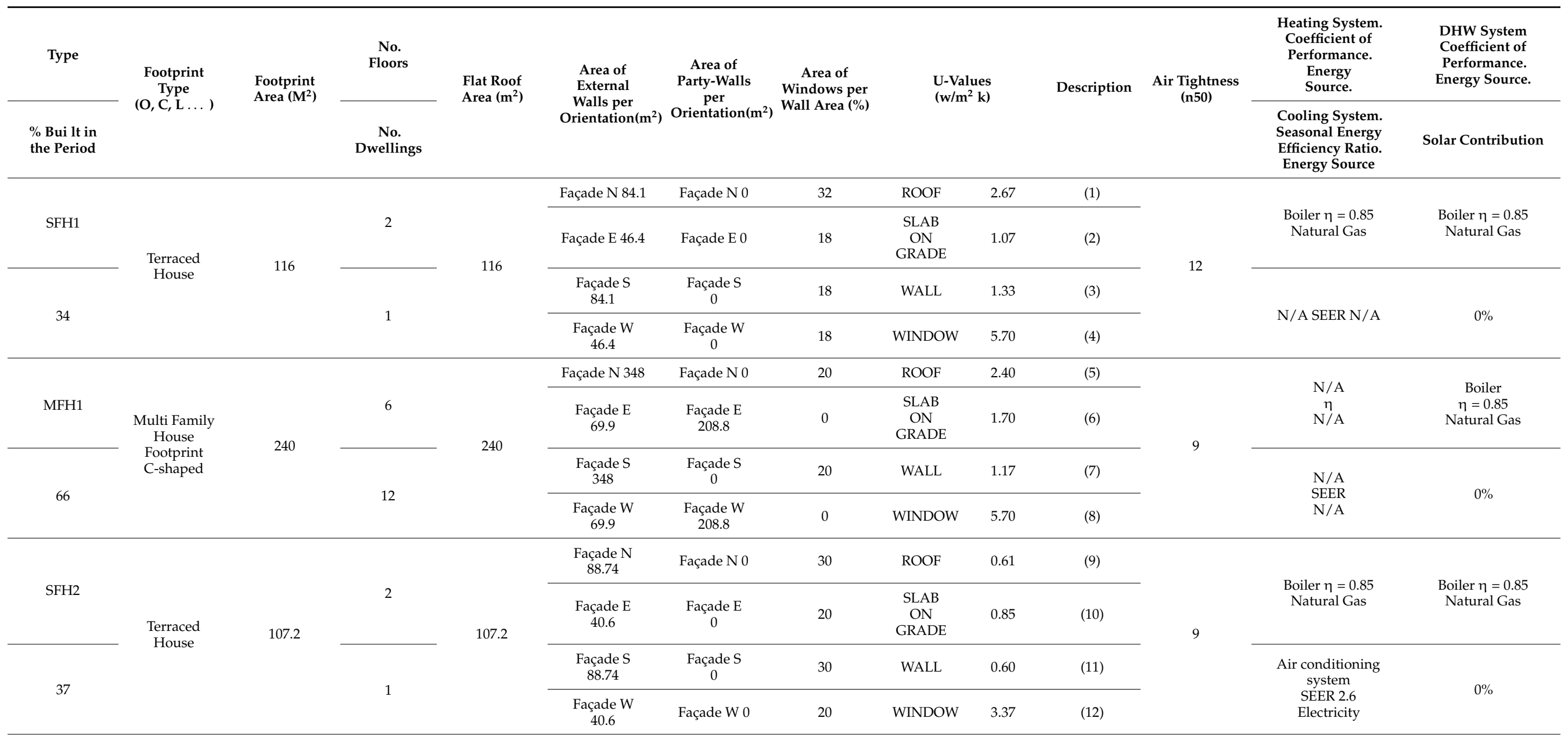


Table A14. Cont.

\begin{tabular}{|c|c|c|c|c|c|c|c|c|c|c|c|c|c|}
\hline Type & \multirow{2}{*}{$\begin{array}{c}\text { Footprint } \\
\text { Type } \\
(\mathrm{O}, \mathrm{C}, \mathrm{L} \ldots)\end{array}$} & \multirow{2}{*}{$\begin{array}{l}\text { Footprint } \\
\text { Area }\left(\mathbf{M}^{2}\right)\end{array}$} & \multirow{2}{*}{$\begin{array}{c}\begin{array}{c}\text { No. } \\
\text { Floors }\end{array} \\
\begin{array}{c}\text { No. } \\
\text { Dwellings }\end{array}\end{array}$} & \multirow{2}{*}{$\begin{array}{l}\text { Flat Roof } \\
\text { Area }\left(m^{2}\right)\end{array}$} & \multirow{2}{*}{$\begin{array}{c}\text { Area of } \\
\text { External } \\
\text { Walls per } \\
\text { Orientation }\left(\mathrm{m}^{2}\right)\end{array}$} & \multirow{2}{*}{$\begin{array}{c}\text { Area of } \\
\text { Party-Walls } \\
\text { per } \\
\text { Orientation }\left(m^{2}\right)\end{array}$} & \multirow{2}{*}{$\begin{array}{c}\text { Area of } \\
\text { Windows per } \\
\text { Wall Area (\%) }\end{array}$} & \multicolumn{2}{|c|}{$\begin{array}{l}\text { U-Values } \\
\left(\mathbf{w} / \mathbf{m}^{2} \mathbf{k}\right)\end{array}$} & \multirow[t]{2}{*}{ Description } & \multirow{2}{*}{$\begin{array}{l}\text { Air Tightness } \\
\text { (n50) }\end{array}$} & \multirow{2}{*}{$\begin{array}{c}\begin{array}{c}\text { Heating System. } \\
\text { Coefficient of } \\
\text { Performance. } \\
\text { Energy } \\
\text { Source. }\end{array} \\
\begin{array}{c}\text { Cooling System. } \\
\text { Seasonal Energy } \\
\text { Efficiency Ratio. } \\
\text { Energy Source }\end{array}\end{array}$} & \multirow{2}{*}{$\begin{array}{c}\begin{array}{c}\text { DHW System } \\
\text { Coefficient of } \\
\text { Performance. } \\
\text { Energy Source. }\end{array} \\
\text { Solar Contributior }\end{array}$} \\
\hline $\begin{array}{l}\% \text { Bui lt in } \\
\text { the Period }\end{array}$ & & & & & & & & & & & & & \\
\hline \multirow[b]{2}{*}{ MFH2 } & \multirow{4}{*}{$\begin{array}{l}\text { Multi Family } \\
\text { House } \\
\text { Footprint } \\
\text { I-shaped }\end{array}$} & \multirow{4}{*}{200} & \multirow[b]{2}{*}{6} & \multirow{4}{*}{200} & $\begin{array}{c}\text { Façade } \mathrm{N} \\
330.6\end{array}$ & Façade N 0 & 38 & ROOF & 0.61 & (9) & & Central Boiler & Boiler \\
\hline & & & & & $\begin{array}{l}\text { Façade } \mathrm{E} \\
\quad 0\end{array}$ & $\begin{array}{l}\text { Façade E } \\
183\end{array}$ & 0 & $\begin{array}{c}\text { SLAB } \\
\text { ON } \\
\text { GRADE }\end{array}$ & 0.85 & (10) & 9 & $\begin{array}{c}\eta=0.85 \\
\text { Natural Gas }\end{array}$ & $\begin{array}{c}\eta=0.85 \\
\text { Natural Gas }\end{array}$ \\
\hline \multirow[t]{2}{*}{63} & & & \multirow[t]{2}{*}{12} & & $\begin{array}{c}\text { Façade S } \\
330.6\end{array}$ & $\begin{array}{c}\text { Façade S } \\
0\end{array}$ & 24 & WALL & 0.60 & (11) & & \multirow{2}{*}{$\begin{array}{c}\text { Individual Air } \\
\text { conditioning system } \\
\text { SEER } 2.6 \\
\text { Electricity } \\
\end{array}$} & \multirow[t]{2}{*}{$0 \%$} \\
\hline & & & & & Façade W 0 & Façade W 183 & 0 & WINDOW & 3.37 & (12) & & & \\
\hline \multirow[b]{2}{*}{ SFH3 } & \multirow{3}{*}{$\begin{array}{l}\text { Terraced } \\
\text { House }\end{array}$} & \multirow{3}{*}{64.5} & \multirow[b]{2}{*}{3} & \multirow{3}{*}{64.5} & Façade N 65.2 & Façade N 0 & 15 & ROOF & 0.48 & (13) & \multirow{3}{*}{6} & & \\
\hline & & & & & $\begin{array}{l}\text { Façade } \mathrm{E} \\
\quad 0\end{array}$ & $\begin{array}{l}\text { Façade } \mathrm{E} \\
74.8\end{array}$ & 0 & $\begin{array}{c}\text { SLAB } \\
\text { ON } \\
\text { GRADE }\end{array}$ & 0.71 & (14) & & $\begin{array}{c}\text { Boiler } \eta=0.95 \\
\text { Natural Gas }\end{array}$ & $\begin{array}{c}\text { Boiler } \eta=0.95 \\
\text { Natural Gas }\end{array}$ \\
\hline 34 & & & 1 & & Façade W 0 & $\begin{array}{c}\text { Façade } \mathrm{W} \\
74.8\end{array}$ & 0 & WINDOW & 3.37 & (12) & & $\begin{array}{l}\text { Air conditioning } \\
\text { system } \\
\text { SEER } 1.8 \\
\text { Electricity } \\
\end{array}$ & $30 \%$ \\
\hline \multirow[b]{2}{*}{ MFH3 } & \multirow{4}{*}{$\begin{array}{l}\text { Multi Family } \\
\text { House } \\
\text { Footprint } \\
\text { L-shaped }\end{array}$} & \multirow{4}{*}{1009.1} & \multirow[b]{2}{*}{7} & & Façade N 447 & $\begin{array}{c}\text { Façade N } \\
191.6 \\
\end{array}$ & 24 & ROOF & 0.48 & (13) & & Central Boiler & 95 \\
\hline & & & & 1009.1 & $\begin{array}{l}\text { Façade E } \\
\quad 447\end{array}$ & $\begin{array}{l}\text { Façade E } \\
191.6\end{array}$ & 24 & $\begin{array}{c}\text { SLAB } \\
\text { ON } \\
\text { GRADE } \\
\end{array}$ & 0.71 & (14) & 6 & $\begin{array}{c}\eta=0.95 \\
\text { Natural Gas }\end{array}$ & Natural Gas \\
\hline & & & & & $\begin{array}{c}\text { Façade S } \\
638.6 \\
\end{array}$ & $\begin{array}{c}\text { Façade } S \\
0\end{array}$ & 24 & WALL & 0.48 & (15) & & $\begin{array}{c}\text { Individual Air } \\
\text { conditioning system }\end{array}$ & $3 \Omega^{\circ}$ \\
\hline 66 & & & 42 & & $\begin{array}{l}\text { Façade } \mathrm{W} \\
638.6\end{array}$ & Façade W 0 & 24 & WINDOW & 3.37 & (12) & & $\begin{array}{l}\text { SEER } 1.8 \\
\text { Electricity }\end{array}$ & $30 \%$ \\
\hline
\end{tabular}




\section{References}

1. European Commission Website. Available online: https://ec.europa.eu/info/news/focus-energy-efficiency-buildings-2020-feb17_en (accessed on 1 September 2021).

2. Mata, É.; Benejam, G.M.; Kalagasidis, A.S.; Johnsson, F. Modelling opportunities and costs associated with energy conservation in the Spanish building stock. Energy Build. 2015, 88, 347-360. [CrossRef]

3. European Commission Website. Available online: https://ec.europa.eu/energy/sites/ener/files/eu_renovation_wave_strategy. pdf (accessed on 1 September 2021).

4. Guardigli, L.; Bragadin, M.A.; Della Fornace, F.; Mazzoli, C.; Prati, D. Energy retrofit alternatives and cost-optimal analysis for large public housing stocks. Energy Build. 2018, 166, 48-59. [CrossRef]

5. Salmerón Lissen, J.M.; Jareño Escudero, C.I.; Sánchez de la Flor, F.J.; Escudero, M.N.; Karlessi, T.; Assimakopoulos, M.-N. Optimal renovation strategies through life-cycle analysis in a pilot building located in a mild mediterranean climate. Appl. Sci. 2021, 11, 1423. [CrossRef]

6. Fotopoulou, A.; Semprini, G.; Cattani, E.; Schihin, Y.; Weyer, J.; Gulli, R.; Ferrante, A. Deep renovation in existing residential buildings through façade additions: A case study in a typical residential building of the 70s. Energy Build. 2018, 166, 258-270. [CrossRef]

7. Salvalai, G.; Sesana, M.M.; Iannaccone, G. Deep renovation of multi-storey multi-owner existing residential buildings: A pilot case study in Italy. Energy Build. 2017, 148, 23-36. [CrossRef]

8. Ramos, J.S.; Domínguez, S.Á.; Moreno, M.P.; Delgado, M.G.; Rodríguez, L.R.; Ríos, J.A.T. Design of the refurbishment of historic buildings with a cost-optimal methodology: A case study. Appl. Sci. 2019, 9, 3104. [CrossRef]

9. Bragadin, M.; Boiardi, L.; Santoni, L. Global Cost Analysis for Energy Refurbishment of Social Housing. In de ISTEA 2014 Proceedings; Maggioli: Rimini, Italy, 2014.

10. Corrado, V.; Ballarini, I. Refurbishment trends of the residential building stock: Analysis of a regional pilot case in Italy. Energy Build. 2016, 132, 91-106. [CrossRef]

11. Brambilla, A.; Salvalai, G.; Imperadori, M.; Sesana, M.M. Nearly zero energy building renovation: From energy efficiency to environmental efficiency, a pilot case study. Energy Build. 2018, 166, 271-283. [CrossRef]

12. Ortiz, J.; Fonseca i Casas, A.; Salom, J.; Garrido Soriano, N.; Fonseca i Casas, P. Cost-effective analysis for selecting energy efficiency measures for refurbishment of residential buildings in Catalonia. Energy Build. 2016, 128, 442-457. [CrossRef]

13. 4RinEU Project Website. Available online: https://4rineu.eu/wp-content/uploads/2021/03/20210224_4RinEU_D-5.5_PotentialRennovation-rate-of-a-building-typology.pdf (accessed on 15 September 2021).

14. Pernetti, R.; Pinotti, R.; Lollini, R. Repository of deep renovation packages based on industrialized solutions: Definition and application. Sustainability 2021, 13, 6412. [CrossRef]

15. Salvati, A.; Coch Roura, H.; Cecere, C. Assessing the urban heat island and its energy impact on residential buildings in Mediterranean climate: Barcelona case study. Energy Build. 2017, 146, 38-54. [CrossRef]

16. Dalla Mora, T.; Righi, A.; Peron, F.; Romagnoni, P. Cost-optimal measures for renovation of existing school buildings towards nZEB. Energy Procedia 2017, 140, 288-302. [CrossRef]

17. Liébana-Durán, M.E.; Serrano-Lanzarote, B.; Ortega-Madrigal, L. Identification of cost-optimal measures for energy renovation of thermal envelopes in different types of public school buildings in the city of Valencia. Appl. Sci. 2021, 11, 5108. [CrossRef]

18. Mateo-Cecilia, C.; Padula, M.; Salmerón, J.; Malvezzi, R. MedZEB: A new holistic approach for the deep energy retrofitting of residential buildings. Techne Res. Philos. Technol. 2018, 127-133. [CrossRef]

19. European Parliament and Council. Directive 2010/31/EU of the European Parliament and of the Council of 19 May 2010 on the Energy Performance of Buildings (Recast); European Union: Brussels, Belgium, 2010.

20. HAPPEN Platform. Available online: https://medzeb-happen.eu/pos-ui/index.html (accessed on 7 September 2021).

21. Loga, T.; Stein, B.; Diefenbach, N. TABULA building typologies in 20 European countries-Making energy-related features of residential building stocks comparable. Energy Build. 2016, 132, 4-12. [CrossRef]

22. Ministerio de Fomento. Documento Basico HE. Ahorro de Energía. Sección HE0 Limitación del Consumo Energético 20 December 2019. Available online: https:/ / www.codigotecnico.org/pdf/Documentos/HE/DccHE.pdf (accessed on 7 October 2021).

23. Ministerio de Fomento. Factores de Emisión de $\mathrm{CO}_{2}$ y Coeficientes de Paso a Energía Primaria de Diferentes Fuentes de Energía Final Consumidas en el Sector de Edificios en España. Available online: https://energia.gob.es/desarrollo/EficienciaEnergetica/ RITE/Reconocidos/Reconocidos/Otros\%20documentos/Factores_emision_CO2.pdf (accessed on 9 November 2021).

24. Instituto Valenciano de la Edificación. Visualizador de Bases de Datos. Base de Precios del IVE 2018. 2018. Available online: https:/ / www.five.es/productos/herramientas-on-line/visualizador-2018/ (accessed on 1 December 2019). 